\title{
Surviving the perfect storm: the role of the lender of last resort
}

\section{Working Papers 2016}

BANCO DE PORTUGAL Nuno Alves | Diana Bonfim | Carla Soares
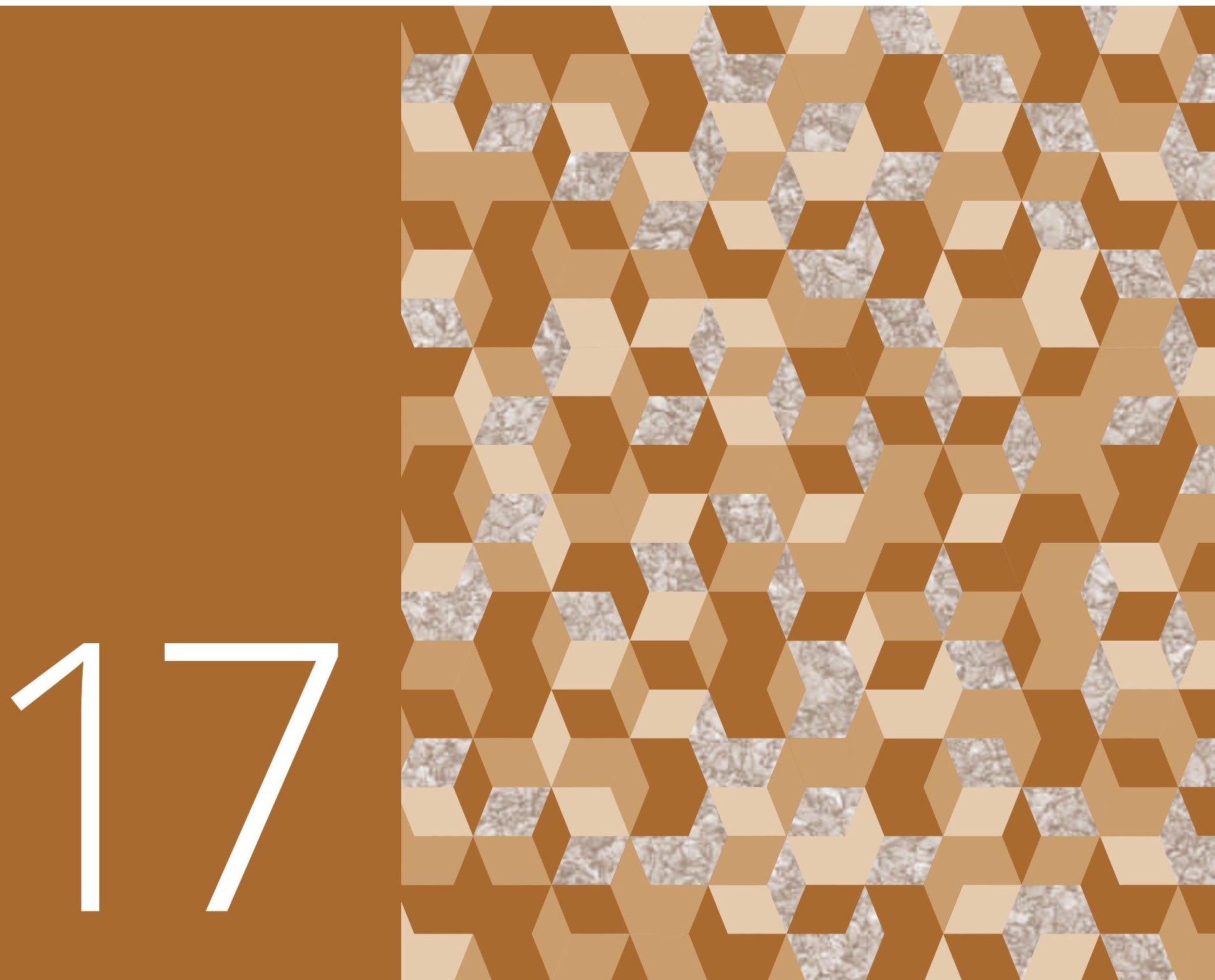



\section{7}

\section{Surviving the perfect storm: the role}

of the lender of last resort

\section{Working Papers 2016}

Nuno Alves | Diana Bonfim | Carla Soares

Please address correspondence to

Banco de Portugal, Economics and Research Department

Av. Almirante Reis 71, 1150-012 Lisboa, Portugal

T+351213130000 | estudos@bportugal.pt

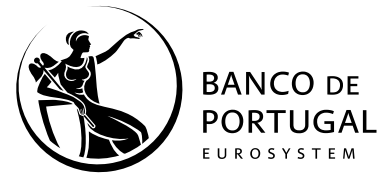

Lisbon, 2016 • www.bportugal.pt 
WORKING PAPERS | Lisbon 2016 • Banco de Portugal Av. Almirante Reis, 71 | 1150-012 Lisboa • www.bportugal.pt • Edition Economics and Research Department • ISBN 978-989-678-479-9 (online) • ISSN 2182-0422 (online) 


\title{
Surviving the perfect storm: the role of the lender of last resort
}

\author{
Nuno Alves \\ Banco de Portugal
}

\section{Diana Bonfim}

Banco de Portugal

\section{Carla Soares}

Banco de Portugal

Nova School of Business and

Economics

September 2016

\begin{abstract}
Acknowledgements: The authors would like to thank Manuel Adelino, Ugo Albertazzi (discussant), Philippe Andrade (discussant), Rui Albuquerque, António Antunes, Andrada Bilan, Isabel Horta Correia, Matteo Crosignani, Hans Degryse, Falko Fecht (discussant), Fernando Ferreira, Miguel Ferreira, Paulo Guimarães, Jochen Guntner (discussant), Isaac Hacamo, Vasso Ioannidou, Victoria Ivashina, Artashes Karapetyan, Catherine Koch (discussant), David Lando, Roland Meeks (discussant), Steven Ongena, Luca Opromolla, Francisca Rebelo, Hugo Reis, Pedro Teles, Anjan Thakor, participants at the ESCB Day Ahead Conference 2015, 9th Lubrafin Conference, 4th UECE Conference, Deutsche Bundesbank Workshop on Financial intermediaries and the real economy: One year after European Banking Union take-off, 2016 IBEFA/ASSA, Third Research Workshop of the Task Force on Banking Analysis for Monetary Policy of the MPC, 9th CEPR Swiss Winter Conference on Financial Intermediation, FEBS-2016, EEA-2016 and participants in seminars at the Banco de Portugal, the Eurosystem Monetary Policy Committee, Nova Research Group, Lisbon Finance Brownbag, Copenhagen Business School and Faculdade de Economia do Porto for insightful comments and suggestions. We would like to thank the Statistics and Market Operations Departments of Banco de Portugal for help with the data used in this paper. The views expressed in this paper are those of the authors and do not reflect the views of the Banco de Portugal or the Eurosystem.

E-mail: njalves@bportugal.pt; dbonfim@bportugal.pt; csoares@bportugal.pt
\end{abstract}




\begin{abstract}
When banks are hit by a severe liquidity shock, central banks have a key role as lenders of last resort. Despite the well-established importance of this mechanism, there is scarce empirical evidence that allows analyzing this key role of central banks. We are able to explore a unique setting in which banks suddenly lose access to market funding due to contagion fears at the onset of the euro area sovereign debt crisis. Using monthly data at the loan, bank, and firm level, we are able to test the role of the central bank in a scenario of imminent collapse. We find that the liquidity obtained from the central bank played a critical role in avoiding the materialization of such a scenario.
\end{abstract}

JEL: E44, E5, G21

Keywords: lender of last resort, monetary policy, credit channel, financial crisis. 


\section{Introduction}

One of the critical functions of central banks is to act as lenders of last resort. When liquidity suddenly dries up, the central bank should stand ready to supply liquidity to distressed banks as long as their solvency is not at risk (Freixas et al. 2000, 2004; Repullo 2005; Rochet and Vives 2004). Despite this critical role, there is scarce empirical evidence on this topic. In this paper we explore a unique event of large scale that might be the perfect lab to assess the role of the lender of last resort in avoiding the collapse of a banking system.

We focus on a large unanticipated shock that hit the Portuguese banking system in the early days of the sovereign debt crisis in the euro area. In May 2010 Portuguese banks suddenly lost access to international medium and long-term wholesale debt markets, which was an important source of their funding. This sudden stop scenario was mainly linked to investors' concerns about contagion from the sovereign crisis that was then emerging in Greece. Portuguese banks then escalated their recourse to Eurosystem monetary operations, which increased by $20 \%$ of GDP in just a few months. Despite this large scale sudden stop, there were no apparent implications in terms of aggregate credit conditions. Against this background, we investigate the role of the ECB in counterbalancing the adverse and unexpected liquidity shock that hit the Portuguese banking system.

The empirical analysis takes advantage of a unique combination of detailed and extensive datasets available for the Portuguese economy. The main dataset used is the Portuguese Central Credit Register (CRC), which has monthly data on virtually all bank loans granted by Portuguese financial institutions to non-financial corporations. Further, we collect monthly information on banks' liquidity, capital, and balance sheet items, as well as on their holdings of Portuguese government bonds. Finally, we also collect bank-level data on the recourse to monetary policy operations and standing facilities, and the collateral pool.

Ensuring a proper identification of the role of the enhanced liquidity provision by the Eurosystem raises considerable challenges. In this respect, several features of the data help in the identification. First, the liquidity shock was arguably exogenous and unanticipated. When Portuguese banks lost access to markets, there were no explicit concerns about financial stability in Portugal. The shock was due to changes in the perception of market players regarding long standing structural vulnerabilities of the Portuguese economy, amidst heightened uncertainty due to the Greek crisis. Second, there was high heterogeneity in the individual banks' recourse to the Eurosystem, both before and after the liquidity shock. In this respect, exploring the heterogeneity across banks at the micro level is helpful in the identification of the main transmission channels. Third, the richness of the data allows a careful identification of demand and supply in the loan market. In particular, we select only firms that have a relationship with more than one bank and employ firm fixed-effects 
estimation in order to control for firm-specific loan demand effects (Khwaja and Mian 2008). Further, bank variables are included at their levels prior to the liquidity shock, in order to mitigate endogenous effects. With this identification strategy, we are able to assess the effect of the expanded liquidity provision on banks' loan supply to non-financial corporations in a sudden stop scenario.

Our results show that access to ECB funding was essential in avoiding a collapse in Portuguese credit markets. Despite the sudden loss of access to wholesale markets, the virtually unlimited access to central bank funding helped banks to continue to provide funding to the real economy. We are not able to find any evidence of major disruptions in loans granted to firms.

Of course not all banks were affected equally by this shock, as their starting points in terms of liquidity and capital played an important role. We find that larger banks and banks with higher capital granted less credit than other banks, for similar increases in central bank funding.

To clearly establish the role of the lender of last resort on banks' balance sheets in this turbulent period, we design a simple counterfactual analysis. The main idea is to show what could have happened to banks' assets if there had been no alternative source of funding when access to wholesale markets suddenly disappeared in May 2010. This allows us to more precisely quantify the magnitude of the shock. Given the strong dependence of the largest Portuguese banks on market funding, we show that a collapse in credit would be unavoidable without the support of a lender of last resort.

Though many things remained surprisingly unchanged after this unprecedented shock, banks' balance sheets did not go unscathed. The increase in ECB funding during this period largely surpassed the liabilities that needed to be refinanced. This led to a (temporary) expansion of banks' balance sheets. We show that at least part of this excess liquidity was channeled to an increase in holdings of domestic sovereign bonds. This is consistent with the idea that there was financial repression in this period, with sovereigns in distress encouraging banks to buy their debt (Becker and Ivashina 2014; Ongena et al. 2016).

Our paper contributes to the empirical literature on the role of the lender of last resort, which is almost nonexistent. One notable recent exception is Drechler et al. (2016). These authors use bank-level data on ECB borrowing and find that euro area banks used this liquidity to engage in risk-shifting strategies, rather than lending to the real economy. In contrast to the scarce empirical evidence, there is an extensive theoretical literature on the role of the lender of last resort, with an emphasis on potentially pervasive moral hazard problems that arise out of this insurance mechanism (Freixas et al. 2004; Gorton and Huang 2004; Ratnovski 2009; Rochet and Tirole 1996; Rochet and Vives 2004; Wagner 2007). More generally, our study is also framed in the flourishing recent line of research on the impact of unconventional measures, in particular using loan-level data (Acharya and Mora 2015; Acharya et al. 2016; Andrade et al. 2015; Cantero-Saiz et al. 2014; Carpinelli and Crosignani 2015; Chakraborty 
et al. 2016; Chodorow-Reich 2014; Crosignani et al. 2016; Daetz et al. 2016; Darracq-Paries and De Santis 2015; Ferrando et al. 2015; Garcia-Posada and Marchetti 2015; Morais et al. 2015; Ramcharan and Yu 2014).

This paper is organized as follows. In Section 2 we discuss the role of a central bank as a lender of last resort, providing also a timeline of the main events in the period analyzed. In Section 3 we describe the data used and in Section 4 we present an overview of what happened with banks during this unique period. In Section 5 we use loan-level data to examine the role of access to central bank funding in corporate lending during this period of near collapse of the financial system. In Section 6 we take an additional step in establishing clearly the role of the lender of last resort in avoiding a collapse of the banking system, by attempting to design a counterfactual scenario. In Section 7 we explore whether banks used ECB funding to buy sovereign debt, amidst an environment of financial repression. In Section 8 we summarize our main findings.

\section{The role of a central bank under a sudden stop scenario}

Bagehot (1873) was among the first to acknowledge the role of the lender of last resort, arguing that "theory suggests, and experience proves, that in a panic the holders of the ultimate bank reserve (whether one bank or many) should lend to all that bring good securities quickly, freely, and readily. By that policy they allay a panic; by every other policy they intensify it." Since then, the consensus has been to lend freely, usually at penalty rates and against good collateral, to all solvent but illiquid banks.

Since then, several models have been designed to better understand the role of the lender of last resort, focusing in particular in the moral hazard problem created by this mechanism (Freixas et al. 2000, 2004; Gorton and Huang 2004; Ratnovski 2009; Rochet and Tirole 1996; Rochet and Vives 2004; Wagner 2007). However, despite these extensive theoretical underpinnings, to the best of our knowledge, there are only a few papers empirically looking at the role of central banks as lender of last resort during the global financial crisis. The paper that is closest to ours is Drechler et al. (2016). Using weekly data on bank-level borrowing from the ECB between August 2007 and December 2011, these authors find that euro area banks used central bank funding to invest in high-yield sovereign debt. This risk-shifting behavior was stronger for weaklycapitalized banks. These findings are inconsistent with the classical predictions of the lender of last resort theory, according to which banks borrow from the lender of last resort to avoid fire sales of their existing asset holdings. This should allow banks to continue lending to the economy, thereby preventing a credit crunch.

Garcia-de-Andoain et al. (2015) examine the role of the ECB as a lender of last resort during the global financial crisis. Using data from interbank 
payments, these authors show that the ECB was able to satisfy the demand for liquidity in the interbank market in the aftermath of the failure of Lehman Brothers. Further, the ECB increased the supply of liquidity in stressed countries during the euro sovereign debt crisis.

Acharya et al. (2016) contrast the role of the ECB as a lender of last resort to that of a buyer of last resort. This amounts to comparing the effect of central bank lending through Long Term Refinancing Operations (LTRO) to the effect of buying assets through Outright Monetary Transactions (OMT). The effects of the announcement of these operations are assessed on sovereign bond yields, sovereign credit default swap spreads, banks' holdings of sovereign bonds, banks' equity prices, banks' credit default swap spreads, and US money market funds' investments in European banks. The authors find that buying assets proved more effective than lending to banks by containing pervasive bank-sovereign feedback loops.

Though de Haan et al. (2015) do not look explicitly at the role of the lender of last resort, these authors do find that borrowing from central banks allowed euro area banks to mitigate the impact of wholesale funding shocks on lending to the real economy.

In this paper we are able to perform a more targeted test of the role of the lender of last resort in a crisis setting. Since the early days of the global financial crisis, the ECB, together with central banks worldwide, actively intervened to restore the transmission of monetary policy and fulfill its mandate. This included not only a series of policy interest rate cuts, but also a large set of unconventional monetary policy measures. In the fall of 2008 the ECB adopted a fixed rate full allotment procedure at its regular refinancing operations, ensuring that all the liquidity needs of banks were met at a fixed interest rate, as long as banks had enough eligible collateral to pledge. Around the same time, the list of assets eligible as collateral was expanded, with several increments in the difficult period that would follow. To some extent, we might argue that in this new setting the ECB's role as a lender of last resort was significantly expanded. During this period the ECB also implemented longerterm refinancing operations (with maturities up to one year), foreign exchange operations, and the Covered Bond Purchase Program. Later on, the ECB implemented the Securities Market Program to purchase sovereign bonds.

These measures implied a considerable expansion of the ECB balance sheet. However, Portuguese banks recorded only a mild increase in their access to ECB funding in this early period of the crisis (2007-08). Indeed, Portuguese banks were not hardly hit by the global financial crisis that followed the collapse of Lehman Brothers, as their exposure to subprime markets and, more generally, to US markets, was residual. Constraints in access to interbank funding during this period were easily accommodated with occasional access to monetary 
policy operations and to the issuance of bonds with government guarantees. ${ }^{1}$ In turn, loan flows were unaffected during this period, with credit growth rates remaining far above those of the euro area, despite the declining trend. In December 2008 the annual growth rate of loans to non-financial corporations stood at $10.5 \%$.

This relatively benign scenario in Portugal suffered a blow in May 2010. Suddenly, Portuguese banks entirely lost access to funding in international wholesale debt markets (Figure 1). ${ }^{2}$ This sudden stop scenario was not due to intrinsic fragilities in the Portuguese banking system. Instead, it reflected the environment of heightened uncertainty in the beginning of the sovereign euro area crisis, when investors were wary of potential contagion from Greece. This sudden loss of access to markets was sizable enough to threaten the survival of many Portuguese banks, which operated with relatively high loan-to-deposit ratios (around 160\% in early-2010). However, despite the high dependence on access to wholesale markets, when we look at credit growth during this period it seems that nothing happened (Figure 2). The annual growth rate of loans to non-financial corporations was stable at around 1\% during 2010, thus implying that banks were refinancing most loans and even extending some new credit. ${ }^{3}$

The answer to this apparent puzzle lies in the lender of last resort support by the ECB. The unconventional measures adopted by the ECB early in the crisis allowed Portuguese banks to easily substitute market funding by ECB loans. In just a few months, the recourse of Portuguese banks to the Eurosystem increased by $20 \%$ of GDP. The evolution of this variable clearly illustrates the unanticipated nature of this shock (Figure 1). If banks were anticipating that they would get into distress, we would expect a gradual increase in this variable over a few months. However, access to Eurosystem funding clearly spiked in May 2010. Note that in this period the Eurosystem did not implement new monetary policy measures and the Eurosystem aggregate excess liquidity remained broadly stable.

Against this background, in this paper we explore this unique setting to empirically assess the role of the lender of last resort in a sudden stop scenario. Our findings will show that the lender of last resort played a key role in allowing banks to survive this perfect storm without jeopardizing financing to the real economy.

1. Interbank markets remained severely impaired for a long period (Acharya and Merrouche 2013; Afonso et al. 2011; Brunnermeier 2009). Iyer et al. (2014) examine the 2007 shock on interbank markets using Portuguese data.

2. "From May 2010 on, Portuguese banks lost access to international medium and longterm wholesale debt markets." Financial Stability Report Banco de Portugal, May 2012.

3. Loan growth rates became negative later, in 2011, when the country was under an international financial assistance program. 


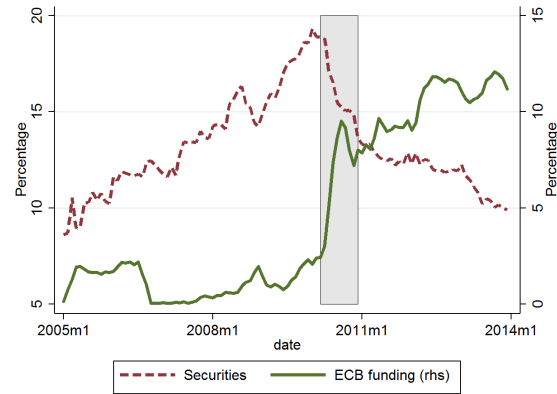

Figure 1: Portuguese banks' funding through securities (lhs) and through the Eurosystem (rhs) as a percentage of total assets

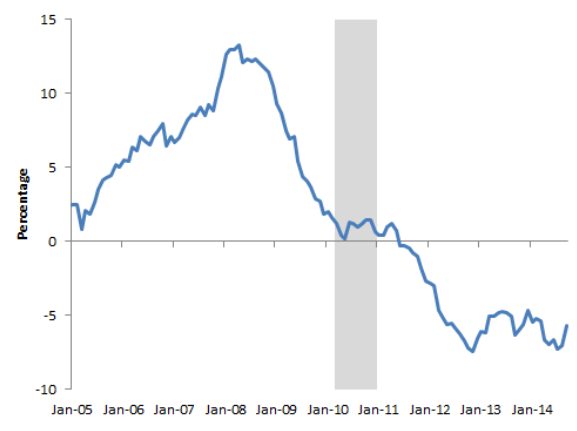

Figure 2: Annual growth rate of loans to non-financial corporations in Portugal. The growth rate is adjusted for securitization operations, reclassifications, write-offs/write-downs, credit portfolio changes, exchange rate changes, and price revaluations.

\section{Data}

We collect monthly data from January 2005 to December 2013 from several datasets. The main dataset has bank loan level data from the Portuguese Central Credit Register (CRC), which is a database managed by Banco de Portugal. The CRC covers virtually all bank loans granted in Portugal (all financial institutions granting credit in Portugal are required to report to the CRC on a monthly basis all loans above 50 euro). We consider only loans granted to non-financial corporations. ${ }^{4}$ The CRC has information on the type of loan, the debtor, and the amount, while also including information on loan defaults and renegotiations, as well as potential credit liabilities associated with irrevocable commitments.

The data on loans are merged with data on banks' characteristics coming from supervisory reports. There are 29 credit institutions eligible to participate in Eurosystem operations that were active in the corporate loan market between March and December 2010. ${ }^{5}$ All institutions report monthly balance sheet data, with the exception of the branches of credit institutions with head office in the EU, which report quarterly. For these, we consider data at end of quarter for the missing months. These branches do not report regulatory capital ratios.

4. de Haan et al. (2015) shows that lending to non-financial firms is more sensitive to wholesale funding shocks than lending to households.

5. In March 2010 there were 42 credit institutions that were eligible to participate in Eurosystem operations. However, 13 were investment banks or credit institutions specialized in consumer credit, thus not granting loans to non-financial corporations. 
We run a regression of regulatory capital ratios on banks' leverage ratios (defined as equity as a percentage of total assets), which is available for all the credit institutions in the sample. We then use the predicted values of these regressions as proxies for the regulatory capital ratio of the five branches of credit institutions with head office in the EU in our database.

We collect monthly data on banks' supervisory liquidity reports. These reports include detailed information for banks' assets and liabilities in several maturity brackets, thereby allowing us to compute liquidity gaps between assets and liabilities in different time horizons. The information included in these reports also allows us to identify the value of eligible assets for Eurosystem operations on banks' balance sheets (including those that are not currently part of the collateral pool).

We collect data at the bank level on the recourse to Eurosystem liquidity by type of operation (both liquidity provision and absorption), and on the pool of eligible assets to refinancing operations. We also collect data on banks' holdings of Portuguese government debt during this period, given its large increase and its relevance in the context of the sovereign debt crisis.

Finally, in order to control for firms' characteristics, we also used data on firms' balance sheet and income statements reported through Informação Empresarial Simplificada (IES). This database covers the entire universe of Portuguese non-financial corporations, given its mandatory nature. The frequency of the data is annual.

Table 1 summarizes the variables used in the analysis of the period in which Portuguese banks lost access to wholesale markets, using loan level data. ${ }^{6}$

6. Table A.1 in the Appendix shows the descriptive statistics for bank level data. 


\begin{tabular}{|c|c|c|c|c|c|c|c|c|}
\hline Variable & $\mathbf{T}$ & Unit & Obs & Mean & Std.Dev. & P25 & Median & P75 \\
\hline $\operatorname{Ln}(\text { assets })_{j}$ & Mar/2010 & $\ln ($ euro $)$ & 218,283 & 24.27 & 1.10 & 23.35 & 24.72 & 25.23 \\
\hline Loan-to-dep ${ }_{j}$ & Mar/2010 & ratio & 218,283 & 164.76 & 30.27 & 144.36 & 161.01 & 180.54 \\
\hline $\operatorname{Liq}$ atio $_{j}$ & Mar/2010 & ratio & 218,283 & 16.60 & 7.81 & 10.26 & 15.46 & 22.00 \\
\hline Solv ratio $_{j}$ & Mar/2010 & ratio & 218,283 & 9.43 & 11.95 & 11.47 & 12.10 & 13.90 \\
\hline ECB funding $g_{j}$ & Mar/2010 & ratio & 217,291 & 0.03 & 0.02 & 0.01 & 0.02 & 0.05 \\
\hline collateral $_{j}$ & Mar/2010 & ratio & 218,283 & 10.82 & 6.03 & 7.45 & 9.20 & 12.87 \\
\hline Liq gap $1 \mathrm{M}-3 \mathrm{M}_{j}$ & Mar/2010 & ratio & 218,283 & -3.27 & 6.36 & -4.55 & -3.53 & -0.72 \\
\hline$\Delta \mathrm{ECB}$ funding ${ }_{j}$ & Mar-Aug/10 & b.p. change & 220,688 & 6.19 & 5.53 & 0.00 & 7.00 & 10.90 \\
\hline$\Delta$ Securities $_{j}$ & Mar-Aug/10 & b.p. change & 201,828 & -2.19 & 5.11 & -3.36 & -3.05 & 0.00 \\
\hline loan growth & Mar-Dec/10 & log change & 188,796 & -10.94 & 67.18 & -24.70 & -2.54 & 1.09 \\
\hline (loan+lines) growth $_{i j}$ & Mar-Dec/10 & log change & 168,469 & -11.12 & 75.40 & -29.59 & -5.77 & 5.18 \\
\hline$\Delta \operatorname{Ln}\left(\right.$ assets ${ }_{j}$ & Mar-Dec/10 & log change & 191,729 & 1.68 & 11.76 & -4.37 & 5.49 & 8.65 \\
\hline$\Delta$ Loan-to-dep ${ }_{j}$ & Mar-Dec/10 & p.p. change & 191,729 & -4.97 & 17.15 & -13.89 & -4.59 & 0.20 \\
\hline
\end{tabular}

TABle 1. Descriptive statistics of the variables used in the analysis

Notes: The index $j$ stands for bank and the index $i$ stands for firm. $T$ is the moment in time to which the statistics refer. Variables description: Ln(assets) is the logarithm of the total assets of the bank. Loan-to-dep is the ratio between total credit granted by the bank and resources from customers. Liq ratio is the amount of liquid assets (cash, loans and advances to credit institutions, and other loans and advances) over total assets. Solv ratio is the prudential total capital ratio. For branches of credit institutions with head office in the EU, which do not report prudential capital ratios, we use the predicted values of a regression of capital ratios on leverage ratios. $E C B$ funding is the total amount of liquidity provided by the Eurosystem net of liquidity deposited at the Eurosystem, over total assets of the bank. Liq gap $1 M-3 M$ is the difference between liquid assets and liabilities with residual maturity between 1 and 3 months as a percentage of stable funding. A higher gap thus represents more liquidity. Collateral is the amount of reported assets in the bank's balance sheet eligible for Eurosystem operations over total assets of the bank. loan growth is the log change of the total amount of effective loans granted by the bank to the borrower. (loans + lines) growth is the log change of the loans including unused credit lines. Securities is the outstanding amount (book-value) of securities issued by each bank. Loan growth rates were winsorized at the 1 st and 99 th percentiles, while the liquidity variables were winsorized at the 5 th and 95 th percentiles.

\section{What happened at the bank level?}

The use of loan-level data is a key source of identification, as discussed above, as it allows us to control for changes in loan demand. Nevertheless, before we explore that information in detail, it may be interesting to have an overview of what happened during this period at the bank level.

Figure 1 shows that the large fall in funding by securities was offset by the sharp increase in access to Eurosystem funding in the Spring and Summer of 2010. While after the collapse of Lehman Brothers in September 2008 there was only a mild and temporary increase in access to these operations, in 2010 the situation was entirely different. Between March and August, the increase in these operations was around $20 \%$ of GDP.

Figure 2 depicts the annual growth rate of loans to non-financial corporations in Portugal. Despite the huge shock on banks' funding, loan growth rates remained broadly stable during this period. Only more than 
one year later, after the request for financial assistance by the Portuguese government, did loan growth rates start to move into negative territory.

These two figures depict the aggregate picture, but it is also worth noting the substantial heterogeneity between banks. Figures 3 to 8 inform us about this heterogeneity, focusing only on potentially exposed banks, i.e., those that issued securities at least once prior to $2010{ }^{7}$ These figures depict the empirical distributions of several bank characteristics using estimated kernel densities weighted by banks' total assets.

Figure 3 shows that even though the average loan-to-deposit ratio was high by international standards, pointing to a strong reliance on access to wholesale debt markets, there is a great deal of dispersion in this measure. Figure 4 complements this idea of dependence from wholesale markets, showing the funding by securities as a percentage of total assets. Moreover, it shows how important the shock was, as the estimated density shifted considerably to the left and became much more concentrated between March and December 2010. Simultaneously, the density of the ECB funding shifted to the right, illustrating the funding substitution (Figure 5).

However, despite the remarkable heterogeneity in the way the shock was felt and in the banks' reaction, the share of loans (including credit lines) on banks' balance sheets barely changed (Figure 6). Moreover, between March and December 2010 the remaining balance sheet items of the banks also remained relatively stable across the entire sample. Figure 7 shows that deposits as a percentage of banks' total assets almost did not change during this period. Further, Figure 8 reveals that the change in banks' total assets was concentrated slightly above zero. This shows, on the one hand, that despite the large and heterogeneous magnitude of the shock to wholesale funding, its impact on banks' total assets and loan portfolios was very homogeneous and hardly visible, and, on the other hand, banks' deposits, which are their main funding source, did not react to or co-move with the shock. ${ }^{8}$

\section{Loan level evidence on the role of the lender of last resort}

\subsection{Identification strategy}

In a crisis environment, in which many things may be happening simultaneously, it is quite challenging to design a proper identification strategy to establish a causal relationship between variables. We do this by exploring

7. These 24 banks represented $60 \%$ of the sample of banks and $94 \%$ of the total assets of the sample in March 2010.

8. The interbank market remained impaired at the time. Changes in interbank assets and liabilities in this period reflect intra-group funding for the largest banking groups. 


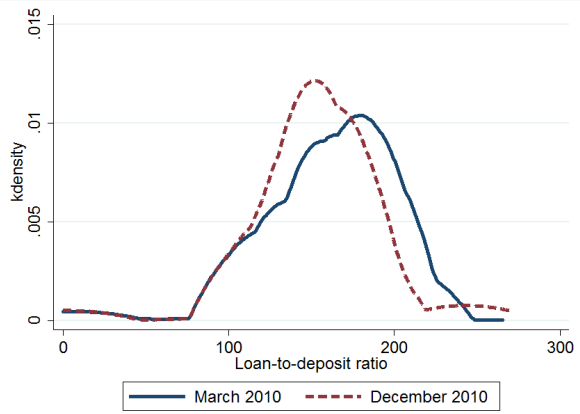

Figure 3: Estimated kernel density of the loan-to-deposit ratio weighted by banks' assets

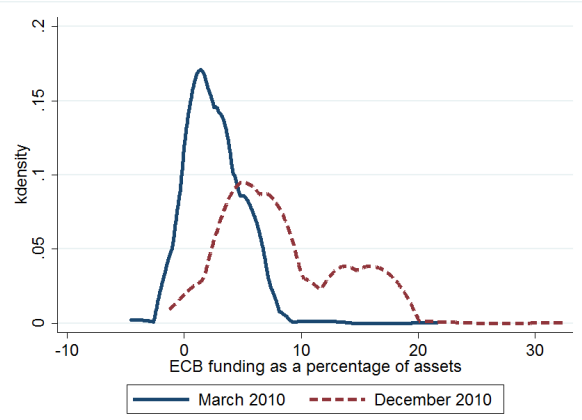

Figure 5: Estimated kernel density of the ECB funding as a share of total assets, weighted by banks' assets

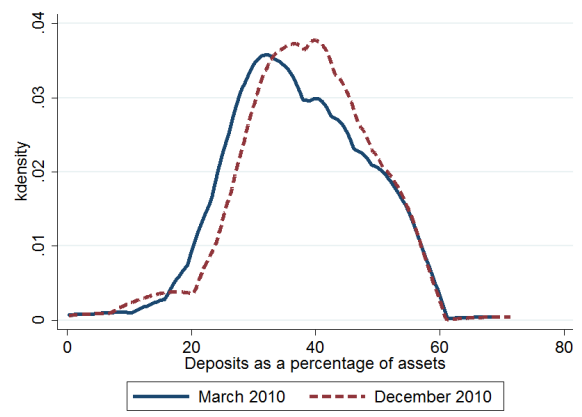

Figure 7: Estimated kernel density of deposits as a share of total assets, weighted by banks' assets

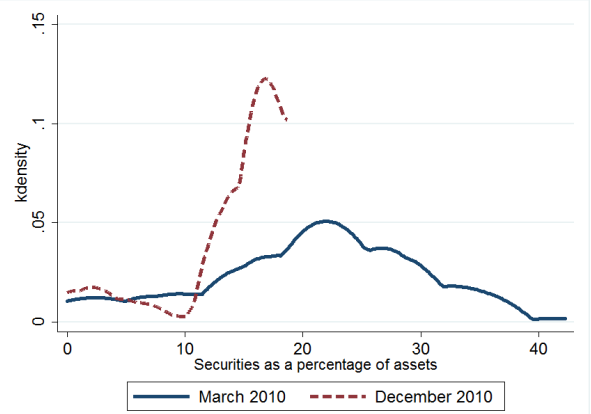

Figure 4: Estimated kernel density of the funding by securities as a share of total assets, weighted by banks' assets

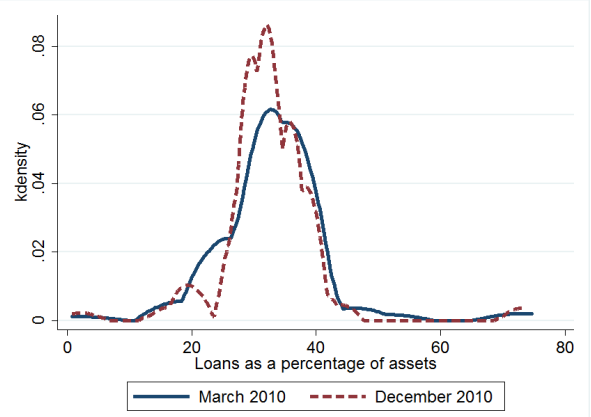

Figure 6: Estimated kernel density of loans to non-financial firms including credit lines as a share of total assets, weighted by banks' assets

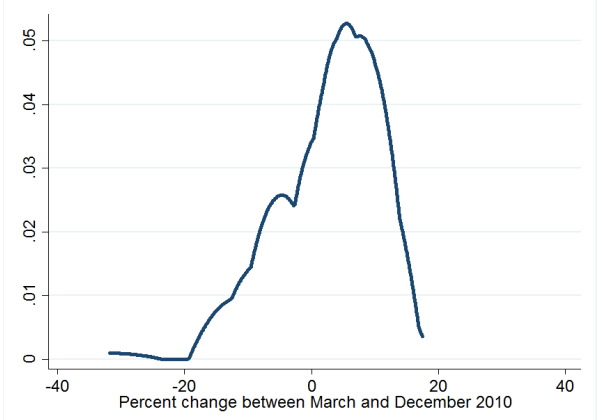

Figure 8: Estimated kernel density of the percent changes in assets between March and December 2010, weighted by banks' assets 
the richness of the dataset available in the quasi-natural experimental setting that we are examining.

The nature of the shock itself helps to create the perfect lab to examine the role of the lender of last resort. The sudden loss of access to wholesale markets by Portuguese banks was largely unexpected, reflecting a sudden rise in investors' risk aversion, amidst growing concerns about the Greek sovereign debt crisis spreading to other vulnerable euro area countries. Given the fragilities of the fiscal and economic situation of the Portuguese economy in that period, investors perceived Portugal to be the next "victim". These concerns actually materialized, but only one year later, with the government asking for international financial assistance. Another important aspect to consider is that the ECB did not adopt any specific measure as a reaction to these events. Portuguese banks were able to benefit from a safety net that had been created during the previous years, including the fixed rate full allotment procedure and the extended list of eligible collateral. These two measures allowed banks to access all the liquidity they wished from the ECB at a fixed rate, using an expanded list of assets that could be used as collateral. Indeed, the collateral constraint was not binding at the time, thus allowing banks to use ECB's monetary policy operations without major limitations.

For identification purposes, it is also worth highlighting the heterogeneity within Portuguese banks. Their situation diverged substantially in terms of their recourse to the Eurosystem, both before and after the liquidity shock. Moreover, banks' dependence on wholesale markets was also heterogeneous, meaning that banks were hit differently by this shock. The same can be said for liquidity and capital buffers. In this respect, exploring the heterogeneity at the micro level is helpful in the identification of the main transmission channels.

Finally, the richness of the data allows for a careful identification of demand and supply in the loan market. Though exploring this event using only banklevel data would allow us to establish some relationships between access to ECB funding and credit dynamics, it is important to note that at this level it would not be possible to control for changes in the demand for bank loans. However, given that we have loan-level data, we are able to select only firms that have a relationship with more than one bank. ${ }^{9}$ This selection, together with firm fixed-effects estimation, allows us to control for firm-specific loan demand effects (Khwaja and Mian 2008), thereby allowing us to explicitly identify credit supply effects at the bank-firm level.

Importantly, to further mitigate endogeneity concerns, all bank variables are included at their levels prior to the liquidity shock.

Our baseline specification is:

9. More than $70 \%$ of the observations in the CRC in 2010 refer to firms with multiple bank relationships. If we exclude micro firms, the percentage goes up to $93 \%$. If we consider the number of firms instead of the number of relationships, $53 \%$ of the firms borrow from more than one bank ( $81 \%$ if we exclude micro firms). 


$$
\text { loan_growt } h_{i j T}=c+\alpha_{i}+\beta \Delta E C B \_ \text {funding }_{j T-4}+\delta X_{j T-9}+\varepsilon_{i j T}
$$

where $T$ refers to December 2010, $\alpha_{i}$ are firm fixed effects and loan growth $_{i j T}$ refers to the log change of loans between March 2010 and December 2010 granted by bank $j$ to firm $i . \Delta E C B \quad$ funding $_{j T-4}$ is the change in ECB funding as a percentage of banks' assets between March 2010 and August 2010. The difference in the time horizons considered intends to capture lags in the process of loan approval. Moreover, the period between March and August captures the peak in access to ECB funding. Finally, $X_{j T-9}$ are a set of bank controls measured before the shock, in March 2010, to mitigate endogeneity concerns.

\subsection{Testing in the perfect lab}

Table 2 shows the results of the empirical strategy discussed above. We begin by running the regressions without controlling for bank characteristics. In the first column we show the results without firm-fixed effects, while in the second column these are included, thereby allowing us to capture all dimensions related to firm demand. In the third column we control for a number of bank characteristics, namely total assets, the loan-to-deposit ratio, the liquidity ratio, and the solvency ratio. This will be our baseline specification. In the fourth column we consider the same specification, but using loan growth excluding unused credit lines as the dependent variable (instead of the total loan exposure). While including unused credit lines allows us to control for the full exposure of a bank to a firm, excluding them allows us to look at the effective outstanding debt of the firm. This latter measure is affected by demand, as firms actively choose to draw down credit lines, most notably in stress scenarios (Carpinelli and Crosignani 2015; Ippolito et al. 2016). In the fifth column we consider all firm-bank relationships, without imposing that firms have multiple relationships and without firm fixed effects. This is a departure from our identification strategy based on Khwaja and Mian (2008). Our goal is to be sure that the results are not affected by using a sample that includes only firms with multiple bank relationships. However, this specification does not allow to control for demand effects.

The effect of the increase of access to ECB funding on firm loan growth is not statistically significant in any of these specifications. This shows that despite the dramatic increase in this funding source (and of its heterogeneity between banks), loan supply to firms remained broadly unchanged. This result confirms the idea that the access to the lender of last resort was essential to avoid a credit crunch.

Our results are consistent with those of Abbassi et al. (2016), who find that German banks who borrowed more from the ECB did not grant significantly more nor less credit to firms than other banks. Note that this result holds in 
a situation that is quite different from that analyzed in our paper, in which the increase in ECB funding was due to a sudden stop scenario for Portuguese banks in wholesale debt markets.

Interestingly, we find that better capitalized banks were able to grant more loans than other banks. The same occurred for banks with more comfortable liquidity positions, though this evidence is weaker.

One important assumption underlying our previous estimations is that the magnitude of the shock is captured by the change in access to ECB funding, given that there were no binding collateral constraints at the time. However, the amount borrowed from the ECB might be an endogeneous choice, most notably given the fixed rate full allotment procedure implemented by the ECB. As such, in Table 3 we explore more directly the effect of the shock that hit Portuguese banks in May 2010. In the first column we report the results exploring the effect of the shock in banks' funding on loan growth. We measure the shock as the change in the outstanding amount of securities issued by each bank between March and August 2010, as a percentage of total assets. In the second column we consider that effect together with the change in ECB funding during the same period. In the third column we add a measure of banks' vulnerability to the shock, captured by the Liq gap 1M-3M in March 2010. Banks with less liquid assets and more short-term liabilities to be refinanced were more exposed to the shock. Regardless of the specification, we still do not find statistically significant effects, thus lending further support to the hypothesis that the ECB successfully avoided a collapse in credit markets in Portugal.

5.2.1. Exploring firm heterogeneity. Even though we do not find any statistically significant impact of access to ECB funding on loan growth, it is possible that firms were affected in different ways. We explore this by running the regression presented in the third column of Table 2 for different groups of firms. We explore differences across firm size cohorts, loan maturities (shortterm versus long-term) and the riskiness of firms (firms in default versus others).

In Table 4 we report the results for different firm size cohorts, i.e., micro, small, medium and large firms. The effect of access to ECB funding is not significant for any firm size category, suggesting that there was no credit crunch in any of these segments of corporate loans in this period.

Even though it seems that banks successfully substituted market funding with ECB funding, we should not forget that this led to a sizeable shortening in the maturities of banks' liabilities. As such, it is possible that long-term loans were more affected by this shock than short-term loans granted by banks. In Table 5 we estimate our baseline regression separately for growth rates of loans in these two maturity segments. We find that there are no visible differences in the maturity of banks' portfolios, despite the shock in the maturity of their liabilities.

Another possibility is that banks used ECB funding to engage in riskshifting strategies by providing loans to riskier borrowers. In Table 6 we show 


\begin{tabular}{|c|c|c|c|c|c|}
\hline & (1) & (2) & (3) & (4) & (5) \\
\hline$\Delta \mathrm{ECB}$ funding $_{j T-4}$ & $\begin{array}{l}-0.0263 \\
(0.352)\end{array}$ & $\begin{array}{l}0.0457 \\
(0.366)\end{array}$ & $\begin{array}{l}-0.118 \\
(0.329)\end{array}$ & $\begin{array}{l}-0.169 \\
(0.388)\end{array}$ & $\begin{array}{l}-0.328 \\
(0.298)\end{array}$ \\
\hline $\operatorname{Ln}\left(\right.$ assets) ${ }_{j T-9}$ & & & $\begin{array}{l}-1.091 \\
(1.550)\end{array}$ & $\begin{array}{l}-1.300 \\
(1.788)\end{array}$ & $\begin{array}{l}-0.263 \\
(1.316)\end{array}$ \\
\hline Loan-to-dep $j T-9$ & & & $\begin{array}{c}-0.0747^{*} \\
(0.0370)\end{array}$ & $\begin{array}{c}-0.0905^{* *} \\
(0.0420)\end{array}$ & $\begin{array}{l}-0.0243 \\
(0.0317)\end{array}$ \\
\hline $\operatorname{Liq} \operatorname{ratio}_{j T-9}$ & & & $\begin{array}{c}0.334^{*} \\
(0.186)\end{array}$ & $\begin{array}{c}0.343 \\
(0.220)\end{array}$ & $\begin{array}{c}0.205 \\
(0.165)\end{array}$ \\
\hline Solv ratio $_{j T-9}$ & & & $\begin{array}{c}0.552^{* * *} * \\
(0.0808)\end{array}$ & $\begin{array}{c}0.578^{* * *} * \\
(0.0946)\end{array}$ & $\begin{array}{c}0.423^{* * *} \\
(0.0680)\end{array}$ \\
\hline Constant & $\begin{array}{c}-10.83^{* * *} \\
(3.614)\end{array}$ & $\begin{array}{c}-11.32^{* * *} \\
(3.541)\end{array}$ & $\begin{array}{c}17.71 \\
(37.98)\end{array}$ & $\begin{array}{c}25.03 \\
(43.17)\end{array}$ & $\begin{array}{l}-5.596 \\
(33.08)\end{array}$ \\
\hline Firm FE & $\mathrm{N}$ & $\mathbf{Y}$ & $\mathbf{Y}$ & $\mathbf{Y}$ & $\mathrm{N}$ \\
\hline Unused credit lines & $\mathbf{Y}$ & $\mathbf{Y}$ & $\mathbf{Y}$ & $\mathrm{N}$ & $\mathbf{Y}$ \\
\hline Relationships & Multiple & Multiple & Multiple & Multiple & All \\
\hline Banks & 29 & 29 & 29 & 29 & 29 \\
\hline Firms & 72772 & 72772 & 68378 & 66266 & 180974 \\
\hline № obs & 182,685 & 182,685 & 178,291 & 159,417 & 316,279 \\
\hline Prob $>$ F & 0.9409 & 0.9016 & 0.0000 & 0.0000 & 0.0000 \\
\hline
\end{tabular}

TABLE 2. Results for the regressions at the loan level

Notes: Dependent variable: Log change in loans at the firm-bank level between March and December 2010. In the first column we report the results without firm fixed effects and without controlling for bank characteristics. In the second column we introduce firm fixed effects. In the third column we introduce bank characteristics. This is our baseline regression. In the fourth column we consider a modified version of the dependent variable, excluding the unused amounts of credit lines from the definition of loan growth. In the fifth column we consider all firm-bank relationships, without imposing that firms have multiple relationships and without firm fixed effects. All variables defined in Table 1. Second line values in parentheses are the robust standard errors clustered at the bank level. * significance at 10 per cent; ${ }^{* *}$ significance at 5 per cent; ${ }^{* * *}$ significance at 1 per cent.

the results of running the baseline regression separately for good and bad quality firms, i.e., firms without or with defaults in the last two consecutive quarters. Again, we cannot find any statistically significant effect of the role of the ECB. The only noteworthy difference is that banks with more capital and liquidity seem to be more prone to risk-taking strategies in this period.

5.2.2. Exploring bank heterogeneity. As shown above, there is substantial heterogeneity in the way banks were affected by the sudden loss of access to wholesale debt markets. Furthermore, Acharya et al. (2015) show that during crises, the transmission of central bank liquidity is impaired, affecting banks differently depending on their soundness. As such, it is quite likely that there are important differences between banks. Thus, in what follows we run additional regressions with subsamples defined according to bank characteristics (bank size, capital, liquidity and collateral availability).

Our first approach is to search for differences based on bank size. The Portuguese banking system is highly concentrated, with the five largest banks having a $70 \%$ market share of the corporate loan market. When we run the 


\begin{tabular}{|c|c|c|c|}
\hline & (1) & (2) & (3) \\
\hline$\Delta$ Securities $_{j T-4}$ & $\begin{array}{c}0.0141 \\
(0.281)\end{array}$ & $\begin{array}{c}0.000219 \\
(0.295)\end{array}$ & $\begin{array}{r}-0.0646 \\
(0.326)\end{array}$ \\
\hline$\Delta \mathrm{ECB}$ funding $_{j T-4}$ & & $\begin{array}{c}-0.101 \\
(0.341)\end{array}$ & \\
\hline $\operatorname{Liq}_{\operatorname{gap}_{j T-9}}$ & & & $\begin{array}{c}0.443 \\
(0.401)\end{array}$ \\
\hline $\operatorname{Ln}(\text { assets })_{j T-9}$ & $\begin{array}{l}-1.871 \\
(1.738)\end{array}$ & $\begin{array}{l}-1.665 \\
(1.805)\end{array}$ & $\begin{array}{l}-0.644 \\
(1.742)\end{array}$ \\
\hline Loan-to-dep $j T-9$ & $\begin{array}{l}-0.0729 \\
(0.0465)\end{array}$ & $\begin{array}{l}-0.0692 \\
(0.0476)\end{array}$ & $\begin{array}{l}-0.0622 \\
(0.0463)\end{array}$ \\
\hline Liq $_{\text {ratio }} j T-9$ & $\begin{array}{c}0.357^{*} \\
(0.196)\end{array}$ & $\begin{array}{c}0.351 \\
(0.206)\end{array}$ & $\begin{array}{c}0.379^{* *} \\
(0.172)\end{array}$ \\
\hline Solv ratio $_{j T-9}$ & $\begin{array}{c}0.567^{* * *} \\
(0.132)\end{array}$ & $\begin{array}{c}0.567^{* * *} \\
(0.129)\end{array}$ & $\begin{array}{c}0.358 \\
(0.252)\end{array}$ \\
\hline Constant & $\begin{array}{c}35.07 \\
(43.19)\end{array}$ & $\begin{array}{c}30.20 \\
(43.84)\end{array}$ & $\begin{array}{c}6.277 \\
(42.07)\end{array}$ \\
\hline Banks & 18 & 18 & 18 \\
\hline Firms & 68260 & 68260 & 68260 \\
\hline № obs & 172,333 & 172,333 & 172,333 \\
\hline Prob $>$ F & 0.0000 & 0.0000 & 0.0000 \\
\hline
\end{tabular}

TABLE 3. Results for the regressions for different measures of the liquidity shock

Notes: Dependent variable: Log change in loans at the firm-bank level, including unused credit lines, between March and December 2010. All regressions include firm fixed effects. In the first column we report the results exploring the effect of the shock in banks' funding on loan growth. We measure the shock as the change in the outstanding amount of securities issued by each bank between March and August 2010, as a percentage of total assets. In the second column we consider that effect together with the change in ECB funding during the same period. In the third column we add a measure of banks' vulnerability to the shock, captured by the Liq gap $1 M-3 M$ in March 2010. All other variables defined in Table 1. Second line values in parentheses are the robust standard errors clustered at the bank level. * significance at 10 per cent; ${ }^{* *}$ significance at 5 per cent; ${ }^{* * *}$ significance at 1 per cent.

regressions separately for these banks, we find some interesting differences (Table 7). For the largest banks we find a large and statistically significant negative effect of access to ECB on loan growth. This means that within these largest banks, those that used ECB funds more intensively, as a percentage of their assets, actually granted less credit to firms. One possibility, to be explored later, is that the larger banks used this funding to increase other assets. The most plausible candidate should be government bonds, given the possible financial repression in a period in which loss of access to markets by banks was preceded by the loss of access by the sovereign (Becker and Ivashina 2014; Ongena et al. 2016). In a way, access to central bank funding might have allowed some banks to smooth, to some extent, the effect of this shock on the government sector. 


\begin{tabular}{rcccc} 
Dependent variable: & loan_growt \\
\hline & Micro & Small & Medium & Large \\
\hline$\Delta$ ECB funding $_{j T-4}$ & -0.0343 & -0.0934 & 0.261 & -0.300 \\
& $(0.352)$ & $(0.348)$ & $(0.324)$ & $(0.546)$ \\
Ln(assets $)_{j T-9}$ & -2.078 & -1.406 & -0.179 & -0.189 \\
& $(1.714)$ & $(2.068)$ & $(1.782)$ & $(3.209)$ \\
Loan-to-dep $_{j T-9}$ & $-0.0815^{*}$ & -0.0834 & $-0.0834^{* *}$ & $-0.122^{*}$ \\
& $(0.0450)$ & $(0.0514)$ & $(0.0343)$ & $(0.0625)$ \\
Liq ratio $_{j T-9}$ & 0.327 & 0.326 & $0.480^{* * *}$ & 0.236 \\
& $(0.232)$ & $(0.193)$ & $(0.123)$ & $(0.248)$ \\
Solv ratio $_{j T-9}$ & $0.445^{* * *}$ & $0.497^{* * *}$ & $0.366^{* * *}$ & $0.245^{*}$ \\
& $(0.0832)$ & $(0.115)$ & $(0.0585)$ & $(0.134)$ \\
Constant & 43.05 & 30.43 & -0.00385 & 13.75 \\
& $(42.78)$ & $(51.78)$ & $(43.10)$ & $(75.10)$ \\
\hline Banks & 25 & 26 & 28 & 26 \\
Firms & 33,030 & 18,101 & 4,115 & 778 \\
No obs & 77,350 & 52,413 & 16,402 & 3,720 \\
Prob $>$ F & 0.0000 & 0.0000 & 0.0000 & 0.1934 \\
\hline
\end{tabular}

TABLE 4. Results for the regressions for different samples according to firm size

Notes: Dependent variable: Log change in loans at the firm-bank level, including unused credit lines, between March and December 2010. All regressions include firm fixed effects. Firm size categories are defined according to the EU Recommendation 2003/361. All other variables are defined in Table 1 . Second line values in parentheses are the robust standard errors clustered at the bank level. * significance at 10 per cent; ${ }^{* *}$ significance at 5 per cent; *** significance at 1 per cent.

\begin{tabular}{rcc} 
Dependent variable: & loan_growt $h_{i j}$ & \\
\hline & Short-term & Long-term \\
\hline$\Delta$ ECB funding $_{j T-4}$ & -0.225 & -0.0749 \\
& $(0.870)$ & $(0.282)$ \\
Ln(assets) ${ }_{j T-9}$ & 0.561 & -1.520 \\
& $(4.202)$ & $(1.470)$ \\
Loan-to-dep $_{j T-9}$ & 0.0254 & -0.0498 \\
& $(0.0915)$ & $(0.0329)$ \\
Liq ratio $_{j T-9}$ & -0.235 & $0.256^{* *}$ \\
& $(0.402)$ & $(0.119)$ \\
Solv ratio $_{j T-9}$ & 0.207 & 0.0657 \\
& $(0.166)$ & $(0.0703)$ \\
Constant & -31.20 & 31.14 \\
& $(92.35)$ & $(37.17)$ \\
\hline Banks & 25 & 26 \\
Firms & 32,736 & 47,739 \\
No obs & 47,415 & 77,477 \\
Prob $>$ F & 0.0400 & 0.1960 \\
\hline
\end{tabular}

TABLE 5. Results for the regressions for different samples according to loan maturity

Notes: Dependent variable: Log change in loans at the firm-bank level, including unused credit lines, between March and December 2010. In the first column we consider only shortterm loans in the dependent variable (i.e., with maturities less than one year). In the second columns we consider only long-term loans (i.e., with maturities above one year). Second line values in parentheses are the robust standard errors clustered at the bank level. * significance at 10 per cent; ${ }^{* *}$ significance at 5 per cent; ${ }^{* *}$ significance at 1 per cent. 


\begin{tabular}{rcc} 
Dependent variable: & loan_growt \\
\hline & Bad & Good \\
\hline$\Delta$ ECB funding $_{j T-4}$ & -0.397 & -0.0368 \\
& $(0.518)$ & $(0.335)$ \\
Ln(assets $)_{j T-9}$ & 0.284 & -1.564 \\
& $(2.062)$ & $(1.783)$ \\
& -0.00709 & $-0.0930^{* *}$ \\
Loan-to-dep $_{j T-9}$ & $(0.0406)$ & $(0.0413)$ \\
& 0.298 & $0.339^{*}$ \\
Liq ratio $_{j T-9}$ & $(0.206)$ & $(0.189)$ \\
& $1.307^{* * *}$ & $0.356^{* * *}$ \\
Solv ratio $_{j T-9}$ & $(0.0660)$ & $(0.0859)$ \\
& -43.09 & 36.80 \\
Constant & $(48.86)$ & $(44.41)$ \\
\hline Banks & 26 & 29 \\
Firms & 15,504 & 52,944 \\
№ obs & 39,107 & 139,184 \\
Prob $>$ F & 0.0000 & 0.0001
\end{tabular}

TABLE 6. Results for the regressions for different samples according to firm recent credit history

Notes: Dependent variable: Log change in loans at the firm-bank level, including unused credit lines, between March and December 2010. All regressions include firm fixed effects. Bad firms are those in default in the current and the past quarter. All the remaining firms are classified as good firms. All other variables are defined in Table 1. Second line values in parentheses are the robust standard errors clustered at the bank level. * significance at 10 per cent; ${ }^{* *}$ significance at 5 per cent; ${ }^{* *}$ significance at 1 per cent.

\begin{tabular}{rcc} 
Dependent variable: & loan_growt \\
\hline & Big $\mathbf{5}$ & \\
\hline$\Delta$ ECB funding $_{j T-4}$ & $-2.244^{* * *}$ & Other banks \\
& $(0.151)$ & -0.203 \\
& $(0.165)$ \\
Ln(assets) $)_{j T-9}$ & $35.45^{* * *}$ & $7.284^{* * *}$ \\
& $(2.949)$ & $(1.616)$ \\
Loan-to-dep $_{j T-9}$ & $0.235^{* * *}$ & -0.0444 \\
& $(0.0237)$ & $(0.0332)$ \\
Liq ratio $_{j T-9}$ & $0.917^{* * *}$ & 0.0496 \\
& $(0.0861)$ & $(0.0802)$ \\
Solv ratio $_{j T-9}$ & - & $0.588^{* * *}$ \\
& - & $(0.0239)$ \\
Constant $^{*}$ & $-934.8^{* * *}$ & $-173.2^{* * *}$ \\
& $(75.27)$ & $(34.65)$ \\
\hline Banks & 5 & 24 \\
Firms & 37,863 & 14,248 \\
No obs & 89,672 & 34,018 \\
Prob $>$ F & 0.0000 & 0.0000 \\
\hline
\end{tabular}

TABLE 7. Results for the regressions for different samples according to bank size

Notes: Dependent variable: Log change in loans at the firm-bank level, including unused credit lines, between March and December 2010. All variables are defined in Table 1. All regressions include firm fixed effects. The solvency ratio is omitted from the large banks' regression due to collinearity. The number of observations is lower than in Tables 2 to 6 because we impose that firms have at least two bank relationships within each subsample of banks. Second line values in parentheses are the robust standard errors clustered at the bank level. ${ }^{*}$ significance at 10 per cent; ${ }^{* *}$ significance at 5 per cent; ${ }^{* * *}$ significance at 1 per cent. 
Another potential source of heterogeneity is bank capital. So far, there seems to be consistent evidence that better capitalized banks granted more credit to firms during this period. To better explore the role of the lender of last resort for banks with different degrees of capitalization, we run additional sample splits based on the median of the empirical distribution of this variable (Table 8). We find a negative and statistically significant effect for the better capitalized banks (i.e., above the median), which, like the largest banks, granted less credit when they used the ECB's facilities more intensively. The magnitude of the effect is also quite large, meaning that an increase of 1 p.p. in the share of ECB funding over total assets implies a fall of 1.9 p.p. in the growth rate of loans to firms. This result is somewhat counterintuitive and might also be related with the financial repression hypothesis. We will return to this issue in Section 7 .

\begin{tabular}{|c|c|c|}
\hline & Below median & Above median \\
\hline$\Delta \mathrm{ECB}$ funding $g_{j T-4}$ & $\begin{array}{c}0.466 \\
(0.293)\end{array}$ & $\begin{array}{c}-1.876^{* * * *} \\
(0.458)\end{array}$ \\
\hline $\operatorname{Ln}(\text { assets })_{j T-9}$ & $\begin{array}{c}-0.876 \\
(0.946)\end{array}$ & $\begin{array}{c}3.329^{* * *} \\
(0.857)\end{array}$ \\
\hline Loan-to-dep ${ }_{j T-9}$ & $\begin{array}{c}-0.0291 \\
(0.0320)\end{array}$ & $\begin{array}{c}-0.0178 \\
(0.0625)\end{array}$ \\
\hline $\operatorname{Liq}^{\operatorname{ratio}_{j}-9}$ & $\begin{array}{c}0.595^{* * *} \\
(0.127)\end{array}$ & $\begin{array}{c}0.00136 \\
(0.129)\end{array}$ \\
\hline Solv ratio $_{j T-9}$ & $\begin{array}{l}0.442^{* * * *} \\
(0.0254)\end{array}$ & $\begin{array}{c}1.245 \\
(0.823)\end{array}$ \\
\hline Constant & $\begin{array}{c}-3.589 \\
(19.10)\end{array}$ & $\begin{array}{c}-88.33^{* *} \\
(34.11)\end{array}$ \\
\hline Banks & 15 & 12 \\
\hline Firms & 19,917 & 19,925 \\
\hline No o obs & 47,525 & 43,516 \\
\hline Prob $>F$ & 0.0000 & 0.0000 \\
\hline
\end{tabular}

TABLE 8. Results for the regressions for different samples according to banks' capital ratio

Notes: Dependent variable: Log change in loans at the firm-bank level, including unused credit lines, between March and December 2010. All regressions include firm fixed effects. The table reports sample splits based on the median of the empirical distribution of the prudential capital ratio. All variables are defined in Table 1. The number of observations is lower than in Tables 2 to 6 because we impose that firms have at least two bank relationships within each subsample of banks. Second line values in parentheses are the robust standard errors clustered at the bank level. * significance at 10 per cent; ${ }^{* *}$ significance at 5 per cent; *** significance at 1 per cent.

Given these interesting differences in terms of bank capital, it is also relevant to consider potential differences in terms of liquidity. Indeed, the shock we are analyzing was primarily a liquidity shock, affecting more substantially the banks that were more reliant on wholesale debt markets. To explore this, we start by running the regressions separately for subsamples of banks determined by their position in the empirical distribution of the loan-to-deposit ratio distribution (Table 9). In this case, we find a statistically significant negative 
effect for the role of ECB funding for the banks with a loan-to-deposit ratio below the median, i.e., those which were arguably less hit by the shock.

We perform a similar exercise for another measure of liquidity, the liquidity gap, which measures the difference between assets and liabilities in a horizon between 1 month and 3 months (Table 10). The banks with a lower liquidity gap, i.e. those with less liquid assets, show a negative coefficient on the recourse to the ECB. This is in line with expectations, as these banks were more vulnerable to the shock.

Finally, we test whether collateral availability leads to any differences (Table 11). Banks with less collateral available for ECB operations might have been more constrained in using this funding source. In line with what we could expect, we find a negative effect for banks with less collateral available and a positive effect for those with greater collateral availability.

\begin{tabular}{|c|c|c|}
\hline & Below median & Above median \\
\hline$\Delta \mathrm{ECB}$ funding $_{j T-4}$ & $\begin{array}{c}-0.736^{*} \\
(0.382)\end{array}$ & $\begin{array}{l}-0.381 \\
(0.346)\end{array}$ \\
\hline $\operatorname{Ln}(\text { assets })_{j T-9}$ & $\begin{array}{c}3.356^{* * *} \\
(0.422)\end{array}$ & $\begin{array}{l}2.306 \\
(2.459)\end{array}$ \\
\hline Loan-to-dep $j T-9$ & $\begin{array}{c}0.145 \\
(0.106)\end{array}$ & $\begin{array}{r}0.0650 \\
(0.118)\end{array}$ \\
\hline Liq $_{\text {ratio }} j T-9$ & $\begin{array}{r}0.0669 \\
(0.261)\end{array}$ & $\begin{array}{l}0.517^{* *} \\
(0.210)\end{array}$ \\
\hline Solv ratio $_{j T-9}$ & $\begin{array}{c}0.584^{* * *} \\
(0.0530)\end{array}$ & $\begin{array}{c}0.395 \\
(0.236)\end{array}$ \\
\hline Constant & $\begin{array}{c}-109.6^{* * *} \\
(14.31)\end{array}$ & $\begin{array}{l}-91.33 \\
(85.41)\end{array}$ \\
\hline Banks & 12 & 15 \\
\hline Firms & 16,262 & 24,310 \\
\hline No obs & 37,837 & 55,528 \\
\hline Prob $>F$ & 0.0000 & 0.0000 \\
\hline
\end{tabular}

TABLE 9. Results for the regressions for different samples according to banks' loanto-deposit ratio

Notes: Dependent variable: Log change in loans at the firm-bank level, including unused credit lines, between March and December 2010. All variables are defined in Table 1. All regressions include firm fixed effects. The table reports sample splits based on the median of the empirical distribution of the loan-to-deposit ratio. The number of observations is lower than in Tables 2 to 6 because we impose that firms have at least two bank relationships within each subsample of banks. Second line values in parentheses are the robust standard errors clustered at the bank level. ${ }^{*}$ significance at 10 per cent; ${ }^{* *}$ significance at 5 per cent; *** significance at 1 per cent.

Finally, to better explore the heterogeneity between banks and grasp potentially different effects of the access to ECB funding, we consider another specification such that:

$$
\begin{aligned}
\text { loan_growth }_{i j T}= & c+\alpha_{i}+\beta \Delta E C B_{\_} \text {funding }_{j T-4} \\
& +\gamma \Delta E C B_{\_} \text {funding } \text { fu }_{j-4} * X_{j T-9}+\delta X_{j T-9}+\varepsilon_{i j T}
\end{aligned}
$$




\begin{tabular}{rcc} 
Dependent variable: & loan_growt $h_{i j}$ & \\
\hline & Below median & Above median \\
\hline$\Delta$ ECB funding $_{j T-4}$ & $-2.203^{* *}$ & 0.987 \\
& $(0.974)$ & $(0.708)$ \\
Ln(assets) ${ }_{j T-9}$ & $6.553^{*}$ & 0.794 \\
& $(3.537)$ & $(2.749)$ \\
Loan-to-dep $_{j T-9}$ & -0.252 & 0.0301 \\
& $(0.165)$ & $(0.0715)$ \\
Liq ratio $j T-9$ & 0.222 & 0.758 \\
& $(0.257)$ & $(0.564)$ \\
Solv ratio $j T-9$ & $0.837^{* *}$ & 3.798 \\
& $(0.310)$ & $(2.767)$ \\
Constant & -118.5 & -89.32 \\
& $(71.02)$ & $(85.73)$ \\
\hline Banks & 14 & 14 \\
Firms & 23,277 & 17,392 \\
No obs & 52,516 & 40,254 \\
Prob $>$ F & 0.0000 & 0.7521 \\
\hline
\end{tabular}

TABLE 10. Results for the regressions for different samples according to bank 1month to 3-month liquidity gap

Notes: Dependent variable: Log change in loans at the firm-bank level, including unused credit lines, between March and December 2010. All variables are defined in Table 1 . All regressions include firm fixed effects. The table reports sample splits based on the median of the empirical distribution of the 1-month to 3 -month liquidity gap. The liquidity gap is defined as the difference between liquid assets and liabilities with residual maturity between 1 and 3 months as a percentage of stable funding. A higher gap thus represents more liquidity. The number of observations is lower than in Tables 2 to 6 because we impose that firms have at least two bank relationships within each subsample of banks. Second line values in parentheses are the robust standard errors clustered at the bank level. * significance at 10 per cent; ${ }^{* *}$ significance at 5 per cent; ${ }^{* * *}$ significance at 1 per cent.

where $\gamma$ captures differential effects of access to ECB funding depending on bank characteristics. The results for the interactions with the loan-to-deposit ratio, the liquidity gap, the eligible collateral, the capital ratio and total assets are shown in Table 12. The goal is to explore some of the effects reported in Tables 7 to 11, but instead of relying on sample splits, using the interactions between changes in ECB funding and each bank's characteristics. The only statistically significant effect comes from the regressions where access to the ECB is interacted with the loan-to-deposit ratio. In this case we find that banks generally granted more credit when they received more funding from the ECB, though this effect is offset for banks with a higher loan-to-deposit ratio. This means that for the banks more affected by the shock, the access to the ECB was possibly not enough to avoid some contraction in lending.

Summing up, we find that the ECB successfully played its role as lender of last resort. Despite the massive shock in access to funding, this had no material impact on banks' ability to grant credit to firms, as they were able to use ECB funding to continue financing the economy. Credit continued to flow to firms, regardless of their size, loan maturity or credit quality. However, for some banks, we find that the larger the amounts they obtained from the ECB, 
Dependent variable: loan_growt $h_{i j}$

\begin{tabular}{rcc}
\hline & Below median & Above median \\
\hline$\Delta$ ECB funding $_{j T-4}$ & $-1.185^{* * *}$ & $1.365^{* * *}$ \\
& $(0.367)$ & $(0.228)$ \\
Ln(assets $)_{j T-9}$ & $6.499^{*}$ & -0.696 \\
& $(3.262)$ & $(0.647)$ \\
Loan-to-dep $_{j T-9}$ & 0.00142 & $-0.0859^{* * *}$ \\
& $(0.0325)$ & $(0.0203)$ \\
Liq ratio $j T-9$ & $0.239^{*}$ & $-0.717^{* * *}$ \\
& $(0.132)$ & $(0.133)$ \\
Solv ratio $j T-9$ & $0.406^{* * *}$ & $3.704^{* * *}$ \\
& $(0.122)$ & $(1.096)$ \\
Constant & $-168.8^{*}$ & -22.09 \\
& $(82.74)$ & $(18.15)$ \\
\hline Banks & 15 & 12 \\
Firms & 13,585 & 20,972 \\
No obs & 30,700 & 48,287 \\
Prob $>$ F & 0.0000 & 0.0000 \\
\hline
\end{tabular}

TABLE 11. Results for the regressions for different samples according to bank collateral availability to Eurosystem operations

Notes: Dependent variable: Log change in loans at the firm-bank level, including unused credit lines, between March and December 2010. All variables are defined in Table 1 . All regressions include firm fixed effects. The table reports sample splits based on the median of the empirical distribution of collateral available for Eurosystem operations. The number of observations is lower than in Tables 2 to 6 because we impose that firms have at least two bank relationships within each subsample of banks. Second line values in parentheses are the robust standard errors clustered at the bank level. * significance at 10 per cent; ** significance at 5 per cent; ${ }^{* * *}$ significance at 1 per cent.

the less they lent to firms. This was the case of the largest banks and the most capitalized. Taken together, this suggests that banks with stronger positions channeled ECB funding elsewhere. In the next section we investigate this issue further.

5.2.3. Further tests. In addition to the results reported in the previous tables, we extend our analysis in several dimensions.

First, we test whether foreign and domestic banks behaved differently during this period. We could argue that domestic banks were more severely affected by the shock, given the stronger bank-sovereign links. Further, foreign banks could more easily obtain funding through their parent banks. At the same time, it is also possible that foreign banks became more reluctant to grant credit during a period of heightened tensions (Haas and Horen 2013; Ongena et al. 2015). When we run our baseline regression separately for domestic and foreign banks, we do not find any differences. For both groups, access to ECB funding enabled banks to continue lending to firms.

Second, we consider the possibility that firms with weaker relationships with their banks could have been more affected by this shock. We define firms with strong relationships with a bank as those that concentrate more than $50 \%$ of 
their borrowing in that bank. Our main results hold both for firms with and without these closer ties with banks.

Finally, all our previous results focus on the intensive margin. This implies that we are only considering firms that were borrowing from a bank before and after the shock. However, the extensive margin may also be important to analyze the role of the ECB during this period, most notably for firms that stopped borrowing from some banks. To explore the extensive margin, we consider firm-bank relationships that existed in December 2010, but not in March 2010 (new relationships) and firm-bank relationships that existed in March 2010, but not in December 2010 (terminated relationships). We find no significant effect from ECB funding on the likelihood of establishing a new relationship. However, we find some tentative evidence that the banks more hardly by the shock and that used more ECB funding were more likely to terminate relationships. However, this result only holds for specifications without firm fixed effects, implying that it might be capturing demand side factors. For instance, it is possible that firms may be more likely to terminate relationships with banks that were more dependent on access to wholesale debt markets.

\begin{tabular}{|c|c|c|c|c|c|}
\hline & & Interact & on term $x_{j}$ & $-9:$ & \\
\hline & LTD & LiqGap 1M-3M & Collateral & Solv ratio & Assets \\
\hline$\Delta$ ECB fund $_{j T-4} * x_{j T-9}$ & $\begin{array}{l}-0.0218^{* *} \\
(0.00929)\end{array}$ & $\begin{array}{c}0.108 \\
(0.0671)\end{array}$ & $\begin{array}{l}0.00907 \\
(0.0149)\end{array}$ & $\begin{array}{l}-0.0779 \\
(0.0459)\end{array}$ & $\begin{array}{c}-0.284 \\
(0.184)\end{array}$ \\
\hline$\Delta \mathrm{ECB}$ funding ${ }_{j T-4}$ & $3.709^{* *}$ & 0.336 & -0.210 & 0.837 & 6.795 \\
\hline & $(1.678)$ & $(0.435)$ & $(0.335)$ & $(0.512)$ & $(4.325)$ \\
\hline $\operatorname{Ln}(\text { assets })_{j T-9}$ & -1.152 & -0.0986 & -0.969 & -0.475 & 0.666 \\
\hline & $(1.223)$ & $(1.485)$ & $(1.539)$ & $(1.775)$ & $(2.413)$ \\
\hline Loan-to-dep $j T-9$ & 0.0385 & $-0.0652^{* *}$ & $-0.0805^{*}$ & $-0.0775^{* *}$ & $-0.0764^{* *}$ \\
\hline & $(0.0596)$ & $(0.0313)$ & $(0.0414)$ & $(0.0349)$ & $(0.0306)$ \\
\hline $\operatorname{Liq} \operatorname{ratio}_{j T-9}$ & 0.222 & $0.397 * *$ & $0.340^{*}$ & 0.327 & $0.360^{*}$ \\
\hline & $(0.164)$ & $(0.158)$ & $(0.191)$ & $(0.195)$ & $(0.184)$ \\
\hline Solv ratio $_{j T-9}$ & $0.451^{* * *}$ & $0.510 * * *$ & $0.553 * * *$ & $0.548^{* * *}$ & $0.519 * * *$ \\
\hline & $(0.0761)$ & $(0.0800)$ & $(0.0805)$ & $(0.0768)$ & $(0.0787)$ \\
\hline Constant & 2.912 & -8.757 & 15.56 & 3.623 & -24.17 \\
\hline & $(29.10)$ & $(37.16)$ & $(37.70)$ & $(42.52)$ & $(57.47)$ \\
\hline Banks & 29 & 29 & 29 & 29 & 29 \\
\hline Firms & 68,378 & 68,378 & 68,378 & 68,378 & 68,378 \\
\hline № obs & 178,291 & 178,291 & 178,291 & 178,291 & 178,291 \\
\hline Prob $>F$ & 0.0000 & 0.0000 & 0.0000 & 0.0000 & 0.0000 \\
\hline
\end{tabular}

TABLE 12. Results for the regressions interacting the recourse to Eurosystem funding with bank characteristics

Notes: Dependent variable: Log change in loans at the firm-bank level, including unused credit lines, between March and December 2010. All variables are defined in Table 1. All regressions include firm fixed effects. In each column we report the results for the estimation of equation 2 with different interactions between $\triangle \mathrm{ECB}$ funding and bank characteristics $x_{j t-9}$. The bank characteristics interacted in each column are reported in the heading of the table. Second line values in parentheses are the robust standard errors clustered at the bank level. ${ }^{*}$ significance at 10 per cent; ${ }^{* *}$ significance at 5 per cent; ${ }^{* * *}$ significance at 1 per cent. 


\section{What if? A counterfactual approach}

To grasp the consequences of what could have been the situation if there had not been a lender of last resort available to provide support to an entire banking system hit by a large and unexpected shock, we design a simple counterfactual scenario. The main idea is to understand what could have happened if there had not been any alternative source of funding when access to wholesale debt markets suddenly evaporated in the Spring of 2010.

To do that, we estimate the following panel regression with bank level data $^{10}$ :

$$
Y_{j t}=c+\alpha_{j}+\beta_{1} \text { securities }_{j t-3}+\beta_{2} X_{j t}+\beta_{3} \text { trend }_{t}+\varepsilon_{j t}
$$

where $Y_{j t}$ refers to total loans or total assets of bank $j$ in period $t$ and $\alpha_{j}$ are bank fixed effects. The coefficient $\beta_{1}$ represents the impact on these bank variables from funding via wholesale markets (securities ${ }_{j t-3}$ refers to the amount outstanding of debt issued by banks in the previous 3 months). $X_{j t}$ is a vector of bank characteristics (including liquidity and capital ratios). The goal of this regression is to explore the structural relationship between funding through wholesale markets and lending to gauge the magnitude of the shock and, in a second step, to understand to what extent ECB funding was successful in substituting market funding. To do that, we first estimate this regression in the pre-shock period (2005-2009). The coefficient $\beta_{1}$ gives us the elasticity of lending or total assets to funding in wholesale markets. Second, we estimate a modified version where we consider the sum of funding through securities and through the ECB, in order to confirm whether central bank funding was relevant in the pre-shock period (given that this value was negligible in this period, we expect the results to be very similar):

$$
\left.Y_{j t}=c+\alpha_{j}+\beta_{1} \text { securities }_{j t-3}+E C B_{j t-3}\right)+\beta_{2} X_{j t}+\beta_{3} \text { trend }_{t}+\varepsilon_{j t}
$$

The next step is to estimate these two equations in the post-shock period (2010-2011). Given the sudden loss of access to markets, we expect that the pre-shock relationship between funding in wholesale markets and lending or total assets breaks down (reflected in a significant change in $\beta_{1}$ in equation 3 ). Adding ECB funding to market funding (by estimating equation 4 for the post shock period) will finally allow us to confirm if the lender of last resort role of the ECB played a part in avoiding a collapse in banks' assets.

As we run the regression in levels, we first confirm that there is a cointegration relationship between the variables with a time trend. This trend

10. In the appendix we report summary statistics for the variables used in these regressions. 
can be related to common factors for Portuguese banks explaining their evolution prior to the crisis. In these regressions we consider only the 24 banks that issued securities at least once prior to 2010 and that were eligible to participate in Eurosystem operations.

Tables 13 and 14 present our results. Table 13 reports the impact on loans to firms (including credit lines) and Table 14 the impact on banks' total assets. In the first two columns of each table we show the results of these estimations using data until 2009. We see that before the shock there was a positive and statistically significant relationship between market funding and banks' loans and assets (column 1). Portuguese banks strongly relied on access to international debt markets to finance their activity. For the average bank, half of the amount financed in the wholesale market would be directed to loans to firms. Moreover, it contributed to leverage banks' balance sheets, as the relationship between securities and total assets is larger than one. In column (2), we estimate the same regressions in the same period, but instead of considering the relationship between securities issued and banks' assets, we consider the sum of securities issues and ECB financing, which was very small at the time (equation 4). Given this, the results are virtually unchanged.

\begin{tabular}{|c|c|c|c|c|}
\hline & \multicolumn{2}{|c|}{ 2005-2009 } & \multicolumn{2}{|c|}{ 2010-2011 } \\
\hline & (1) & (2) & (3) & (4) \\
\hline $\operatorname{securities}_{j t-3}$ & $\begin{array}{c}0.555^{* * *} * \\
(0.0422)\end{array}$ & & $\begin{array}{c}-0.112^{* *} \\
(0.0413)\end{array}$ & \\
\hline$(\text { securities }+\mathrm{ECB})_{j t-3}$ & & $\begin{array}{c}0.480 * * * \\
(0.0954)\end{array}$ & & $\begin{array}{c}-0.110^{*} \\
(0.0620)\end{array}$ \\
\hline $\operatorname{Liq}_{\text {ratio }} j t-12$ & $\begin{array}{c}-8.811^{* * *} \\
(3.046)\end{array}$ & $\begin{array}{c}-8.250^{*} \\
(4.089)\end{array}$ & $\begin{array}{c}4.204 \\
(6.120)\end{array}$ & $\begin{array}{c}8.631 \\
(8.436)\end{array}$ \\
\hline Solv ratio $_{j t-12}$ & $\begin{array}{c}8.179 \\
(15.42)\end{array}$ & $\begin{array}{c}13.84 \\
(21.55)\end{array}$ & $\begin{array}{c}48.39 \\
(35.18)\end{array}$ & $\begin{array}{l}66.11^{*} \\
(33.98)\end{array}$ \\
\hline trend & $\begin{array}{l}19.73^{* *} \\
(7.621)\end{array}$ & $\begin{array}{c}26.80^{* *} \\
(12.12)\end{array}$ & $\begin{array}{l}-18.46 \\
(15.47)\end{array}$ & $\begin{array}{c}-7.218 \\
(16.33)\end{array}$ \\
\hline Constant & $\begin{array}{c}4,214^{* * *} \\
(349)\end{array}$ & $\begin{array}{c}4,795^{* * *} \\
(511)\end{array}$ & $\begin{array}{c}9,344^{* * * *} \\
(1,319)\end{array}$ & $\begin{array}{c}8,599^{* * *} \\
(1,315)\end{array}$ \\
\hline Banks & 24 & 18 & 19 & 18 \\
\hline № obs & 1,032 & 864 & 436 & 427 \\
\hline Prob $>F$ & 0.0000 & 0.0000 & 0.0315 & 0.1186 \\
\hline
\end{tabular}

TABLE 13. Results for the panel regression at the bank level for the evolution of loans (including credit lines) to non-financial firms

Notes: All variables are defined in Table 1. The dependent variable is total loans granted by banks, including unused credit lines. In columns 1 and 3 we report the results for the estimation of equation (3) in the periods before (2005-2009) and after (2010-2011) the shock, respectively. In columns 2 and 4 we report the results for the estimation of equation (4) for the same two periods. All regressions include bank fixed effects. Second line values in parentheses are the robust standard errors. ${ }^{*}$ significance at 10 per cent; ${ }^{* *}$ significance at 5 per cent; ${ }^{* * *}$ significance at 1 per cent. 


\begin{tabular}{|c|c|c|c|c|}
\hline & \multicolumn{2}{|c|}{ 2005-2009 } & \multicolumn{2}{|c|}{ 2010-2011 } \\
\hline & (1) & (2) & (3) & (4) \\
\hline $\operatorname{securities}_{j t-3}$ & $\begin{array}{c}1.597^{* * *} \\
(0.143)\end{array}$ & & $\begin{array}{l}0.0539 \\
(0.132)\end{array}$ & \\
\hline$(\text { securities }+\mathrm{ECB})_{j t-3}$ & & $\begin{array}{c}1.444^{* * *} \\
(0.227)\end{array}$ & & $\begin{array}{c}0.352^{* * *} \\
(0.0792)\end{array}$ \\
\hline Liq $_{\text {ratio }} j t-12$ & $\begin{array}{c}-27.54^{* *} \\
(12.94)\end{array}$ & $\begin{array}{l}-27.26 \\
(18.62)\end{array}$ & $\begin{array}{c}17.67 \\
(21.40)\end{array}$ & $\begin{array}{c}43.76 \\
(38.06)\end{array}$ \\
\hline Solv ratio $_{j t-12}$ & $\begin{array}{c}68.38 \\
(52.21)\end{array}$ & $\begin{array}{c}85.43 \\
(70.41)\end{array}$ & $\begin{array}{c}115.1 \\
(68.11)\end{array}$ & $\begin{array}{c}80.41 \\
(61.62)\end{array}$ \\
\hline trend & $\begin{array}{l}88.16^{* *} \\
(32.83)\end{array}$ & $\begin{array}{l}108.9^{* *} \\
(44.25)\end{array}$ & $\begin{array}{c}23.61 \\
(48.83)\end{array}$ & $\begin{array}{c}13.27 \\
(42.54)\end{array}$ \\
\hline Constant & $\begin{array}{c}9,992^{* * *} \\
(1,148)\end{array}$ & $\begin{array}{c}11,052^{\text {**** }} \\
(1,503)\end{array}$ & $\begin{array}{c}21,615^{\text {**** }} \\
(4,443)\end{array}$ & $\begin{array}{c}20,829^{* * * *} \\
(3,903)\end{array}$ \\
\hline Banks & 23 & 18 & 19 & 18 \\
\hline No obs & 1,031 & 864 & 436 & 427 \\
\hline Prob $>F$ & 0.0000 & 0.0000 & 0.2278 & 0.0017 \\
\hline
\end{tabular}

TABLE 14. Results for the panel regression at the bank level for the evolution of total assets

Notes: All variables are defined in Table 1. The dependent variable is banks' total assets. In columns 1 and 3 we report the results for the estimation of equation (3) in the periods before (2005-2009) and after (2010-2011) the shock, respectively. In columns 2 and 4 we report the results for the estimation of equation (4) for the same two periods. All regressions include bank fixed effects. Second line values in parentheses are the robust standard errors. * significance at 10 per cent; ${ }^{* *}$ significance at 5 per cent; ${ }^{* *}$ significance at 1 per cent.

In columns (3) and (4) we show the same regressions as in columns (1) and (2), but for the 2010-2011 period ${ }^{11}$. If our hypothesis is correct, we would expect the positive relationship between loans or assets and securities to break. However, this relationship should hold when we include ECB funding if this is a quasi-perfect substitute for the lost wholesale market funding. The results are indeed strikingly different from those of the first period, confirming our hypothesis: the positive correlation between outstanding debt securities and banks' assets entirely disappears. The coefficient is not statistically significant for total assets (Table 14) and is actually negative for loans (Table 13). The more market debt outstanding banks had, the lower their stock of loans to firms during this period. This result is consistent with Dagher and Kazimov (2015), who find that there is a negative relation between wholesale funding and the supply of credit, but only during the global financial crisis.

In the last column we consider the joint effect of securities issued and access to ECB funding in the crisis period, in order to test if access to the central bank allowed to restore the previous relationship between securities and loans to firms. For loans we still obtain a negative coefficient. Given that in these regressions we are not controlling for demand effects, unlike what we

11. If the estimation is done only for 2010, the results described below are generally consistent. 
did when using loan level data, it is possible that this result is being affected by a contraction of loan demand in a period of strong adjustment of expectations.

In contrast, when we look at the effect on total assets, we find a positive coefficient, showing that access to the lender of last resort was indeed critical to avoid a collapse in the banking system. This coefficient is smaller than those of columns (1) and (2), suggesting that ECB funding did not perfectly substitute securities issuance. The results on loans and on total assets suggest that the replacement of securities funding by ECB funding was likely used for other purposes than granting loans to firms.

\section{Where did the money go?}

This last result, together with other results obtained earlier with the loan-level regressions, hints at the hypothesis that banks used ECB funding to invest in assets other than loans to firms. These results are consistent with the hypothesis of financial repression presented by Becker and Ivashina (2014) and Ongena et al. (2016). These authors argue that during this period sovereigns in distress encouraged banks to buy their debt. To test this hypothesis in our setting, we estimate the following equation:

$$
\operatorname{Sov}_{j t}=c+\alpha_{j}+\beta_{1}\left(E C B_{j t-3}\right)+\beta_{2} X_{j t}+\beta_{3} \text { trend }_{t}+\varepsilon_{j t}
$$

where $\operatorname{Sov}_{j t}$ are the holdings of Portuguese sovereign bonds by banks. The results are shown in Table 15.

The first column shows the results for the period 2005-2009 and no correlation is found between the two variables. However, for the period 20102011 we observe a positive correlation between ECB funding and holdings of sovereign debt, thus providing support to the financial repression hypothesis. These results are consistent with those of Drechler et al. (2016). Using weekly data on bank-level ECB borrowing, these authors find that euro area banks used central bank funding to invest in distressed sovereign debt instead of channeling funds to the real economy. 


\begin{tabular}{rcc}
\multicolumn{2}{c}{ Dependent variable: Holdings of domestic sovereign bonds $j$} \\
\hline & $\mathbf{2 0 0 5 - 2 0 0 9}$ & $\mathbf{2 0 1 0 - 2 0 1 1}$ \\
\hline ECB funding $j t-3$ & 0.0271 & $0.204^{* * *}$ \\
& $(0.0372)$ & $(0.0480)$ \\
Liq ratio $j t-12$ & -3.403 & -6.956 \\
& $(2.571)$ & $(17.09)$ \\
Solv ratio $j t-12$ & 14.49 & -5.547 \\
& $(15.52)$ & $(16.90)$ \\
trend & $5.651^{*}$ & 0.328 \\
& $(2.724)$ & $(10.44)$ \\
Constant & -97.42 & 651.8 \\
& $(290.2)$ & $(887.4)$ \\
\hline Banks & 16 & 15 \\
$\mathrm{~N} 0$ obs & 705 & 331 \\
Prob $>$ F & 0.1522 & 0.0002 \\
\hline
\end{tabular}

TABLE 15. Results for the panel regression at the bank level for the evolution of Portuguese sovereign bond holdings

Notes: All variables are defined in Table 1. The dependent variable is total Portuguese government bond holdings. The table reports the results for the estimation of equation (3) in the periods before (2005-2009) and after (2010-2011) the shock, in columns 1 and 2, respectively. All regressions include bank fixed effects. Second line values in parentheses are the robust standard errors. ${ }^{*}$ significance at 10 per cent; ${ }^{* *}$ significance at 5 per cent; ${ }^{* * *}$ significance at 1 per cent.

We should recall that the Portuguese government also lost access to markets in the Spring of 2010. As such, we argue that the increase in sovereign holding by Portuguese banks during this period was likely more related with financial repression and moral suasion effects, as discussed by Becker and Ivashina (2014) and Ongena et al. (2016), instead of pure risk-shifting incentives, as discussed in Acharya et al. (2014) and Drechler et al. (2016). Actually, it is possible to argue that in that moment lending to the sovereign was actually less risky for banks, given the uncertainty regarding the prospects for an overly indebted corporate sector. The difference in risk weights on these two exposures also provided incentives for banks to prefer this type of allocation of resources. Further, the loan level results presented in Table 4 also do not support the risk-shifting hypothesis.

In sum, we find that the positive relationship between securities issued and banks' loans and total assets observed before 2010 broke after banks lost access to markets. Unlimited access to the ECB successfully helped banks to substitute market funding, leaving banks' assets virtually unchanged. However, this new funding is not directed only to loans to non-financial firms. Banks also used these funds to buy sovereign bonds, in a period in which the sovereign also faced difficulties in access to markets. Our results thus suggest that the ECB played a dual role as lender of last resort during this period: on one hand it allowed banks to maintain loan flows to the private sector, avoiding a collapse in credit markets, while on the other hand it allowed the distressed sovereign to 
refinance some of its maturing debt. Without this support, the consequences for the financial system and for the economy as a whole could have been dramatic.

\section{Concluding remarks}

What happens when an entire banking system suddenly loses access to debt markets? At the very least, a credit crunch might follow. More likely, the entire economy will be disrupted.

In the recent past, Portuguese banks went through an episode that could easily fit this description. In the early days of the euro sovereign debt crisis, when distress in Greece started to assume large-scale proportions, international investors suddenly became unwilling to provide funding to Portuguese banks, due to concerns about the sustainability of sovereign debt levels. Despite the magnitude of this shock, credit flows during this period were virtually unchanged. This is even more surprising when we consider that Portuguese banks were highly dependent on market funding, as their loan-to-deposit ratios were around $160 \%$.

The answer to this puzzle has one very obvious solution: the ECB monetary policy framework allowed banks to obtain all the liquidity they needed almost immediately and without major implications on funding costs.

In this paper we argue that this "perfect storm" scenario is also the perfect setting to study empirically something that has been absent from the literature: the role of the lender of last resort. By exploring very detailed bank data, we are able to document the critical role of the central bank in avoiding the collapse of the financial system and, consequently, of the economy. We show that even though funding with the central bank increased dramatically over the course of a few months, credit flows to firms remained broadly stable. At the same time, banks were able to play an important role in the financing of the sovereign, who also lost access to markets in this period. Without the supporting role of the lender of last resort, a collapse of the banking system would possibly have been unavoidable. 


\section{References}

Abbassi, Puriya, Rajkamal Iyer, José-Luis Peydró, and Francesc R. Tous (2016). "Securities trading by banks and credit supply: Micro-evidence from the crisis." Journal of Financial Economics, 121(3), 569-594.

Acharya, Viral, Diane Pierret, and Sascha Steffen (2016). "Lender of last resort versus buyer of last resort: The impact of the European Central Bank actions on the bank-sovereign nexus." Tech. rep.

Acharya, Viral V, Tim Eisert, Christian Eufinger, and Christian Hirsch (2014). "Real Effects of the Sovereign Debt Crisis in Europe: Evidence from Syndicated Loans." CEPR Discussion Papers 10108, C.E.P.R. Discussion Papers.

Acharya, Viral V., Björn Imbierowicz, Sascha Steffen, and Daniel Teichmann (2015). "Does Lack of Financial Stability Impair the Transmission of Monetary Policy?"' Working Paper Series 24, Institute of Economic Research, Hitotsubashi University.

Acharya, Viral V. and Ouarda Merrouche (2013). "Precautionary Hoarding of Liquidity and Interbank Markets: Evidence from the Subprime Crisis." Review of Finance, 17(1), 107-160.

Acharya, V.V. and N. Mora (2015). "A Crisis of Banks as Liquidity Providers." Journal of Finance, 70(1), 1-43.

Afonso, Gara, Anna Kovner, and Antoinette Schoar (2011). "Stressed, Not Frozen: The Federal Funds Market in the Financial Crisis." Journal of Finance, 66(4), 1109-1139.

Andrade, P., C. Cahn, H. Fraisse, and J-S. Mésonnier (2015). "Can the Provision of Long-Term Liquidity Help to Avoid a Credit Crunch? Evidence from the Eurosystem's LTROs." Working papers 540, Banque de France.

Bagehot, Walter (1873). Lombard Street, A Description of the Money Market.

Becker, B. and V. Ivashina (2014). "Financial repression in the European sovereign debt crisis." mimeo.

Brunnermeier, Markus K. (2009). "Deciphering the Liquidity and Credit Crunch 2007-2008." Journal of Economic Perspectives, 23(1), 77-100.

Cantero-Saiz, M., S. Sanfilippo-Azofra, B. Torre-Olmo, and C. López-Gutiérrez (2014). "Sovereign risk and the bank lending channel in Europe." Journal of International Money and Finance, 47(C), 1-20.

Carpinelli, Luisa and Matteo Crosignani (2015). "The Effect of Central Bank Liquidity Injections on Bank Credit Supply." mimeo.

Chakraborty, Indraneel, Itay Goldstein, and Andrew MacKinlay (2016). "Monetary Stimulus and Bank Lending." mimeo.

Chodorow-Reich, Gabriel (2014). "Effects of Unconventional Monetary Policy on Financial Institutions." Brookings Papers on Economic Activity, 48(1 (Spring), 155-227.

Crosignani, Matteo, Miguel Faria-e-Castro, and Luis Fonseca (2016). "The (Unintended?) Consequences of the Largest Liquidity Injection Ever." 2016 
Meeting Papers 43, Society for Economic Dynamics.

Daetz, Stine L., Marti G. Subrahmanyam, Dragon Y. Tang, and Sarah Q. Wang (2016). "Did ECB Liquidity Injections Help The Real Economy in Europe? The Impact of Unconventional Monetary Interventions on Corporate Policies." mimeo.

Dagher, Jihad and Kazim Kazimov (2015). "Banks' liability structure and mortgage lending during the financial crisis." Journal of Financial Economics, 116(3), 565-582.

Darracq-Paries, Matthieu and Roberto A. De Santis (2015). "A non-standard monetary policy shock: The ECB's 3-year LTROs and the shift in credit supply." Journal of International Money and Finance, 54(C), 1-34.

de Haan, Leo, Jan Willem van den End, and Philip Vermeulen (2015). "Lenders on the storm of wholesale funding shocks: Saved by the central bank?" DNB Working Papers 456, Netherlands Central Bank, Research Department.

Drechler, I., T. Drechsel, D. Marquez-Ibanez, and P. Schnabl (2016). "Who Borrows from the Lender of Last Resort?" The Journal of Finance, 71(5), 1933-1974.

Ferrando, Annalisa, Alexander Popov, and Gregory F. Udell (2015). "Sovereign stress, unconventional monetary policy, and SME access to finance." Working Paper Series 1820, European Central Bank.

Freixas, X., B. Parigi, and J.C. Rochet (2004). "The lender of last resort: a twenty-first century approach." Journal of the European Economic Association, 2(6), 1085-1115.

Freixas, Xavier, Curzio Giannini, Glenn Hoggarth, and Farouk Soussa (2000). "Lender of Last Resort: What Have We Learned Since Bagehot?" Journal of Financial Services Research, 18(1), 63-84.

Garcia-de-Andoain, Carlos, Florian Heider, Marie Hoerova, and Simone Manganelli (2015). "Lending-of-last-resort is as lending-of-last-resort does: Central bank liquidity provision and interbank market functioning in the euro area." CEPR Discussion Papers 10901, C.E.P.R. Discussion Papers.

Garcia-Posada, M. and M. Marchetti (2015). "The bank lending channel of Unconventional Monetary Policy: the impact of the VLTROs on credit supply in Spain." Working papers 1512, Banco de España.

Gorton, Gary and Lixin Huang (2004). "Liquidity, Efficiency, and Bank Bailouts." American Economic Review, 94(3), 455-483.

Haas, Ralph De and Neeltje Van Horen (2013). "Running for the Exit? International Bank Lending During a Financial Crisis." Review of Financial Studies, 26(1), 244-285.

Ippolito, Filippo, José-Luis Peydró, Andrea Polo, and Enrico Sette (2016). "Double Bank Runs and Liquidity Risk Management." Journal of Financial Economics, (forthcoming).

Iyer, Rajkamal, José-Luis Peydró, Samuel da Rocha-Lopes, and Antoinette Schoar (2014). "Interbank Liquidity Crunch and the Firm Credit Crunch: Evidence from the 2007-2009 Crisis." Review of Financial Studies, 27(1), 
$347-372$.

Khwaja, Asim Ijaz and Atif Mian (2008). "Tracing the Impact of Bank Liquidity Shocks: Evidence from an Emerging Market." American Economic Review, 98(4), 1413-42.

Morais, Bernardo, Jose Luis Peydro, and Claudia Ruiz (2015). "The International Bank Lending Channel of Monetary Policy Rates and QE: Credit Supply, Reach-for-Yield, and Real Effects." International Finance Discussion Papers 1137, Board of Governors of the Federal Reserve System (U.S.).

Ongena, Steven, José-Luis Peydró, and Neeltje van Horen (2015). "Shocks Abroad, Pain at Home? Bank-Firm-Level Evidence on the International Transmission of Financial Shocks." IMF Economic Review, 63(4), 698-750.

Ongena, Steven, Alexander Popov, and Neeltje Van Horen (2016). "The invisible hand of the government: "Moral suasion" during the European sovereign debt crisis." CEPR Discussion Papers 11153, C.E.P.R. Discussion Papers.

Ramcharan, Rodney and Edison $\mathrm{Yu}$ (2014). "The Real Effects of Unconventional Monetary Policy: Some Micro Evidence." mimeo.

Ratnovski, Lev (2009). "Bank liquidity regulation and the lender of last resort." Journal of Financial Intermediation, 18(4), 541-558.

Repullo, Rafael (2005). "Liquidity, Risk Taking, and the Lender of Last Resort." International Journal of Central Banking, 1(2).

Rochet, Jean-Charles and Jean Tirole (1996). "Interbank Lending and Systemic Risk." Journal of Money, Credit and Banking, 28(4), 733-62.

Rochet, Jean-Charles and Xavier Vives (2004). "Coordination Failures and the Lender of Last Resort: Was Bagehot Right After All?" Journal of the European Economic Association, 2(6), 1116-1147.

Wagner, Wolf (2007). "Aggregate liquidity shortages, idiosyncratic liquidity smoothing and banking regulation." Journal of Financial Stability, 3(1), 1832. 


\section{Appendix}

\begin{tabular}{rrrrrrrr}
\hline Variable & Unit & Obs & Mean & Std. Dev. & P25 & Median & P75 \\
\hline Loans + lines & Million euro & 3,629 & 4,211 & 8136 & 113 & 723 & 3,653 \\
Loans & Million euro & 3,629 & 3,269 & 6,128 & 93 & 557 & 3,186 \\
Assets & Million euro & 3,591 & 12,505 & 23,509 & 758 & 2,347 & 7,706 \\
Securities & Million euro & 3,629 & 1,685 & 4,191 & 0 & 0 & 495 \\
ECB funding & Million euro & 2,891 & 821 & 2,278 & 0 & 0 & 310 \\
PT bonds & Million euro & 2,085 & 609 & 1,228 & 6 & 82 & 543 \\
Liq ratio & ratio & 3,615 & 25.6 & 23.8 & 9 & 17 & 37 \\
Solv ratio & ratio & 3,622 & 12.1 & 13.6 & 9 & 11 & 14 \\
\hline
\end{tabular}

TABLE A.1. Descriptive statistics of the variables used in the analysis at the bank level 


\section{WORKING PAPERS}

\section{3}

01|13 Macroeconomic forecasting using lowfrequency filters

João Valle e Azevedo | Ana Pereira

02|13 Everything you always wanted to know about sex discrimination

Ana Rute Cardoso | Paulo Guimarães | Pedro Portugal

03|13 Is there a role for domestic demand pressure on export performance?

Paulo Soares Esteves | António Rua

04|13 Ageing and fiscal sustainability in a small euro area economy

Gabriela Castro | José R. Maria | Ricardo Mourinho Félix | Cláudia Rodrigues Braz

05|13 Mind the gap! The relative wages of immigrants in the Portuguese labour market Sónia Cabral | Cláudia Duarte

06|13 Foreign direct investment and institutional reform: Evidence and an application to Portugal

Paulo Júlio | Ricardo Pinheiro-Alves | José Tavares

07|13 Monetary policy shocks: We got news! Sandra Gomes | Nikolay Iskrev | Caterina Mendicino

08|13 Competition in the Portuguese Economy: Estimated price-cost margins under imperfect labour markets

João Amador | Ana Cristina Soares

09|13 The sources of wage variation: a threeway high-dimensional fixed effects regression model

Sonia Torres | Pedro Portugal | John T. Addison | Paulo Guimarães
10|13 The output effects of (non-separable) government consumption at the zero lower bound

Valerio Ercolani | João Valle e Azevedo

11|13 Fiscal multipliers in a small euro area economy: How big can they get in crisis times?

Gabriela Castro | Ricardo M. Felix | Paulo Julio | Jose R. Maria

12|13 Survey evidence on price and wage rigidities in Portugal

Fernando Martins

13|13 Characterizing economic growth paths based on new structural change tests Nuno Sobreira | Luis C. Nunes | Paulo M. M. Rodrigues

14|13 Catastrophic job destruction Anabela Carneiro | Pedro Portugal | José Varejão

$15 \mid 13$ Output effects of a measure of tax shocks based on changes in legislation for Portugal

Manuel Coutinho Pereira | Lara Wemans

16|13 Inside PESSOA - A detailed description of the model

Vanda Almeida | Gabriela Castro | Ricardo M. Félix | Paulo Júlio | José R. Maria

17|13 Macroprudential regulation and macroeconomic activity

Sudipto Karmakar

18|13 Bank capital and lending: An analysis of commercial banks in the United States Sudipto Karmakar | Junghwan Mok 


\section{4}

1|14 Autoregressive augmentation of MIDAS regressions

Cláudia Duarte

2|14 The risk-taking channel of monetary policy - exploring all avenues

Diana Bonfim | Carla Soares

3|14 Global value chains: Surveying drivers, measures and impacts

João Amador | Sónia Cabral

4|14 Has US household deleveraging ended? a model-based estimate of equilibrium debt

Bruno Albuquerque | Ursel Baumann | Georgi Krustev

5|14 The weather effect: estimating the effect of voter turnout on electoral outcomes in italy

Alessandro Sforza

6|14 Persistence in the banking industry: fractional integration and breaks in memory Uwe Hassler | Paulo M.M. Rodrigues | Antonio Rubia

7|14 Financial integration and the great leveraging Daniel Carvalho

8|14 Euro area structural reforms in times of a global crisis

Sandra Gomes

9|14 Labour demand research: towards a better match between better theory and better data

John T. Addison | Pedro Portugal | José Varejão
10|14 Capital inflows and euro area long-term interest rates

Daniel Carvalho | Michael Fidora

11|14 Misallocation and productivity in the lead up to the Eurozone crisis

Daniel A. Dias | Carlos Robalo Marquesz | Christine Richmond

12|14 Global value chains: a view from the euro area

João Amador | Rita Cappariello | Robert Stehrer

13|14 A dynamic quantitative macroeconomic model of bank runs

Elena Mattana | Ettore Panetti

14|14 Fiscal devaluation in the euro area: a model-based analysis

S. Gomes | P. Jacquinot | M. Pisani

15|14 Exports and domestic demand pressure: a dynamic panel data model for the euro area countries

Elena Bobeica | Paulo Soares Esteves | António Rua | Karsten Staehr

16|14 Real-time nowcasting the US output gap: singular spectrum analysis at work Miguel de Carvalho | António Rua 
1|15 Unpleasant debt dynamics: can fiscal consolidations raise debt ratios?

Gabriela Castro | Ricardo M. Félix | Paulo Júlio | José R. Maria

2|15 Macroeconomic forecasting starting from survey nowcasts

João Valle e Azevedo | Inês Gonçalves

3|15 Capital regulation in a macroeconomic model with three layers of default

Laurent Clerc | Alexis Derviz | Caterina Mendicino | Stephane Moyen | Kalin Nikolov | Livio Stracca | Javier Suarez | Alexandros P. Vardoulakis

4|15 Expectation-driven cycles: time-varying effects

Antonello D'Agostino | Caterina Mendicino

5|15 Seriously strengthening the tax-benefit link

Pedro Portugal | Pedro S. Raposo

6|15 Unions and collective bargaining in the wake of the great recession

John T. Addison | Pedro Portugal | Hugo Vilares

7|15 Covariate-augmented unit root tests with mixed-frequency data

Cláudia Duarte

8|15 Financial fragmentation shocks

Gabriela Castro | José R. Maria | Paulo úlio | Ricardo M. Félix

9|15 Central bank interventions, demand for collateral, and sovereign borrowing cost Luís Fonseca | Matteo Crosignani | Miguel Faria-e-Castro
10|15 Income smoothing mechanisms after labor market transitions

Nuno Alves | Carlos Martins

11|15 Decomposing the wage losses of displaced workers: the role of the reallocation of workers into firms and job titles Anabela Carneiro | Pedro Raposo | Pedro Portugal

12|15 Sources of the union wage gap: results from high-dimensional fixed effects regression models

John T. Addison | Pedro Portugal | Hugo Vilares

13|15 Assessing european firms' exports and productivity distributions: the compnet trade module Antoine Berthou | Emmanuel Dhyne | Matteo Bugamelli | Ana-Maria Cazacu | Calin-Vlad Demian | Peter Harasztosi | Tibor Lalinsky | Jaanika Meriküll | Filippo Oropallo | Ana Cristina Soares

14|15 A new regression-based tail index estimator: an application to exchange rates

João Nicolau | Paulo M. M. Rodrigues

15|15 The effect of bank shocks on firm-level and aggregate investment João Amador | Arne J. Nagengast

16|15 Networks of value added trade João Amador | Sónia Cabral

17|15 House prices: bubbles, exuberance or something else? Evidence from euro area countries Rita Fradique Lourenço | Paulo M. M. Rodrigues 


\section{6}

1|16 A mixed frequency approach to forecast private consumption with ATM/POS data

Cláudia Duarte | Paulo M. M. Rodrigues | António Rua

2|16 Monetary developments and expansionary fiscal consolidations: evidence from the EMU

António Afonso | Luís Martins

3|16 Output and unemployment, Portugal, 2008-2012

José R. Maria

4|16 Productivity and organization in portuguese firms

Lorenzo Caliendo | Luca David Opromolla | Giordano Mion | Esteban Rossi-Hansberg

5|16 Residual-augmented IVX predictive regression

Matei Demetrescu | Paulo M. M. Rodrigues

6|16 Understanding the public sector pay gap Maria M. Campos | Evangelia Papapetrou | Domenico Depalo Javier J. Pérez | Roberto Ramos

7|16 Sorry, we're closed: Ioan conditions when bank branches close and firms transfer to another bank

Diana Bonfim | Gil Nogueira | Steven Ongena

8|16 The effect of quantitative easing on lending conditions

Laura Blattner | Luísa Farinha | Gil Nogueira
9|16 Market integration and the persistence of electricity prices

João Pedro Pereira | Vasco Pesquita | Paulo M. M. Rodrigues | António Rua

10|16 EAGLE-FLI | A macroeconomic model of banking and financial interdependence in the euro area

N. Bokan | A. Gerali | S. Gomes | P. Jacquinot M. Pisani

11|16 Temporary contracts' transitions: the role of training and institutions

Sara Serra

12|16 A wavelet-based multivariate multiscale approach for forecasting António Rua

13|16 Forecasting banking crises with dynamic panel probit models

António Antunes | Diana Bonfim | Nuno Monteiro | Paulo M. M. Rodrigues

14|16 A tale of two sectors: why is misallocation higher in services than in manufacturing? Daniel A. Dias | Carlos Robalo Marques | Christine Richmond

15|16 The unsecured interbank money market: a description of the Portuguese case Sofia Saldanha

16|16 Leverage and risk weighted capital requirements

Leonardo Gambacorta | Sudipto Karmakar

17|16 Surviving the perfect storm: the role of the lender of last resort

Nuno Alves | Diana Bonfim | Carla Soares 


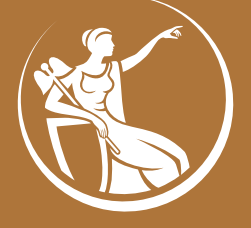

